Historic, Archive Document

Do not assume content reflects current scientific knowledge, policies, or practices. 



\section{A SHORT}

to the best varieties of Evergreens, Shade Trees, Shrubs, Forestry Seedlings, Transplants, etc., with special quantity prices applying for the Spring of 1928,

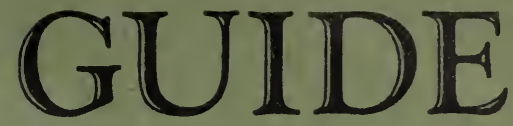

\section{L $1 \leqslant 0.45$

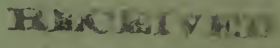 * MAR L J jyLY +

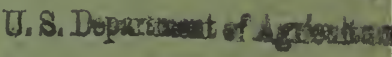

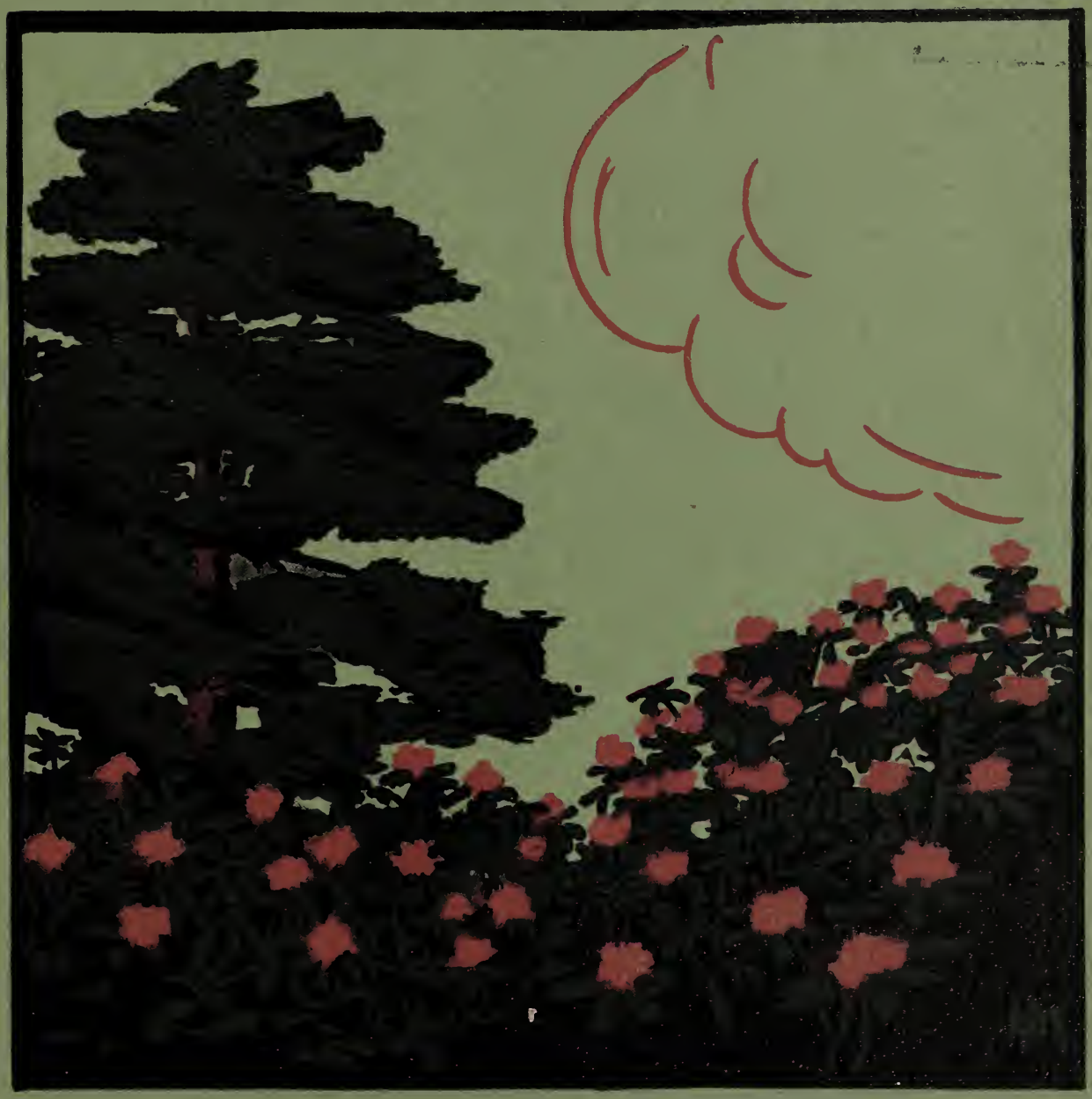

FIFTIETH ANNIVERSARY KELSEY NURSERY SERVICE 


\section{Kelsey Nursery Service}

1. We furnish high quality stock. Kelsey Nursery stock is grown where it grows best; always, of course, with regard to shipping convenience. Of more than seventy nurseries with over twenty thousand acres of stock we select the nearest nursery growing the material of the quality and grade you may want.

2. We furnish our stock at the lowest prices made possible by mass production. Prices of nursery stock vary greatly. One nursery grows stock on land worth, say, $\$ 1,000$ or $\$ 5,000$ per acre. The stock is no better than that grown at a nearby nursery where land is worth perhaps $\$ 400.00$ per acre. Nature has no partiality in this respect. We are, therefore, enabled to sell excellent stock at very low prices.

3. We are an entirely responsible source of supply. Established Fifty Years ago, in 1878 , we still have among our customers many who have been patrons for forty years or more. In all our dealings we are always willing to make things right on any errors or just causes for complaint.

4. Our Guarantee-Stock to be in good condition when furnished. We will, however, replace any and all losses at half price.

5. Scarce and rare varieties:-Why look through a dozen nursery catalogues for them? Send us your list and we will quote promptly. This Short Guide is necessarily confined to standard varieties, but with our facilities we can furnish almost any variety or size grown in the United States.

Large Specimens-We have them and will gladly quote on request.

Normal Sizes-(Varieties not listed will be quoted on request.)

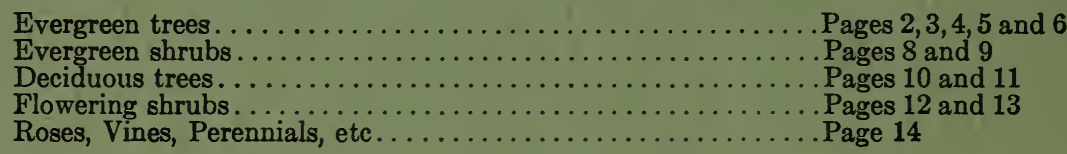

Hedge and Screen Grade-Page 7.

Seedlings and Transplants-green insert in back of book.

\section{CONSULT US BEFORE BUYING}

Supplying all young stock in quantity for reforesting and for nursery planting on the most favorable terms is one of the important and well-knowm features of the KELSEY NURSERY SERVICE. That these facilities are more and more appreciated by past and prospective patrons is shown in our constantly increasing business.

It is, therefore, advantageous, especially where material quantities are required, to get in touch with us before making purchases.

Throughout this list, 5 will be supplied at the 10 rate, 25 at the 100 and 250 at the 1000 rate.

\section{F. W. KELSEY NURSERY GOMPANY Fifty Church Street New York Gity}

\section{Telephones: Cortland 6380 and 2123} Cables: Kelnurco, Newyork
Fred'k. W. Kelsey, President
L. E. Manning, Vice-president and Manager 


\section{F I F T Y Y A R S-}

THIS page is a record in brief of fifty years successful business. In 1Sis Mr. Frederick W. Kelsey; president of the company, founded the business which was to continue for a half century - and still remains - a growing business. To our many customers, some of whom have been patrons of this company almost since the first year, we offer increased facilities to give entire satisfaction.
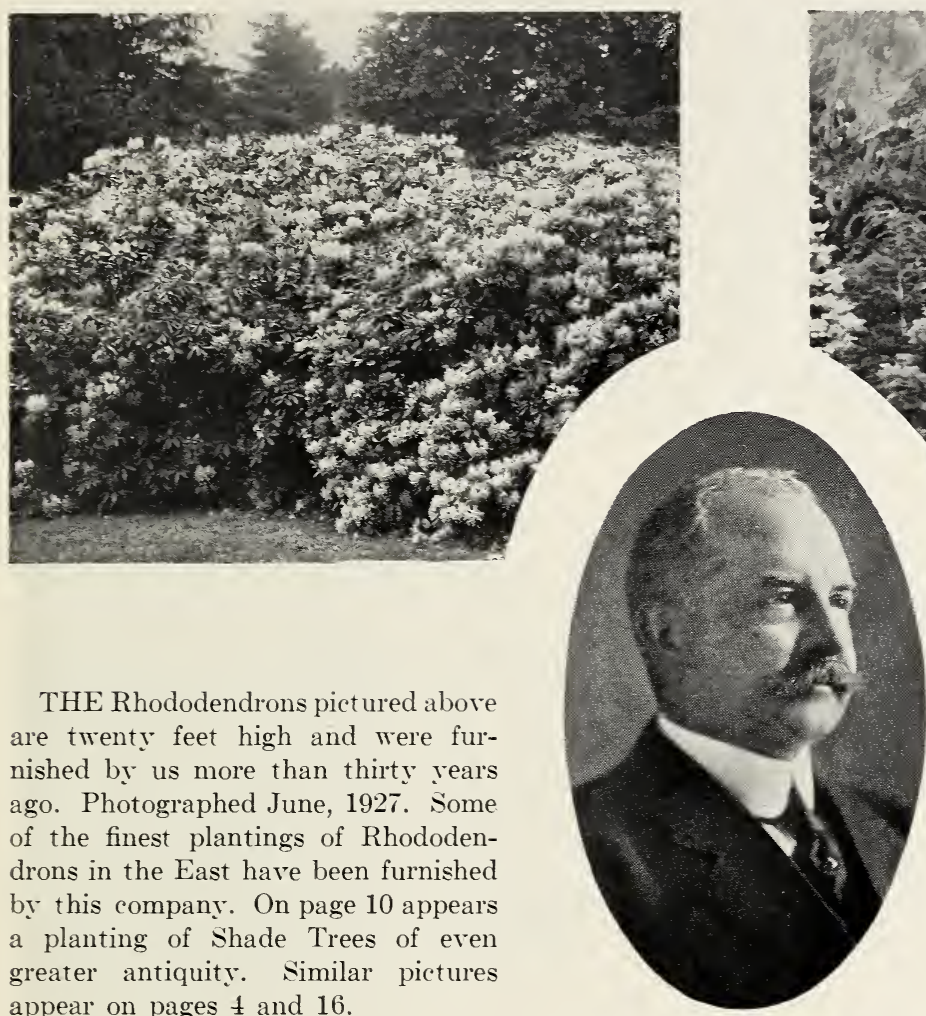

Mr. Fred'k. W. Kelsey President
THE Rhododendrons pict ured above are twenty feet high and were furnished by us more than thirty years ago. Photographed June, 1927. Some of the finest plantings of Rhododendrons in the East have been furnished by this company. On page 10 appears a planting of Shade Trees of even greater antiquity. Similar pictures appear on pages 4 and 16 .

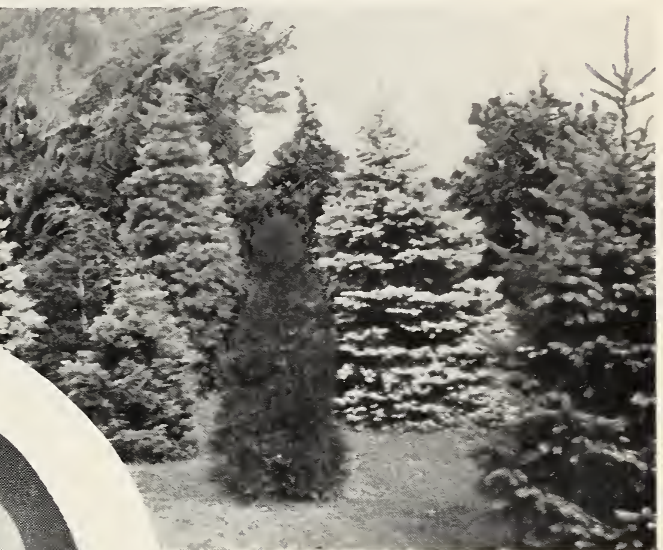

THE evergreens above were snapped by a customer last summer and although the picture is imperfect and required to be "touched up" we printed it to show the shapely and bushy growth. Twelve years ago we furnished these evergreens-small ones, but so grown and cared for that when set out they grew into specimens.
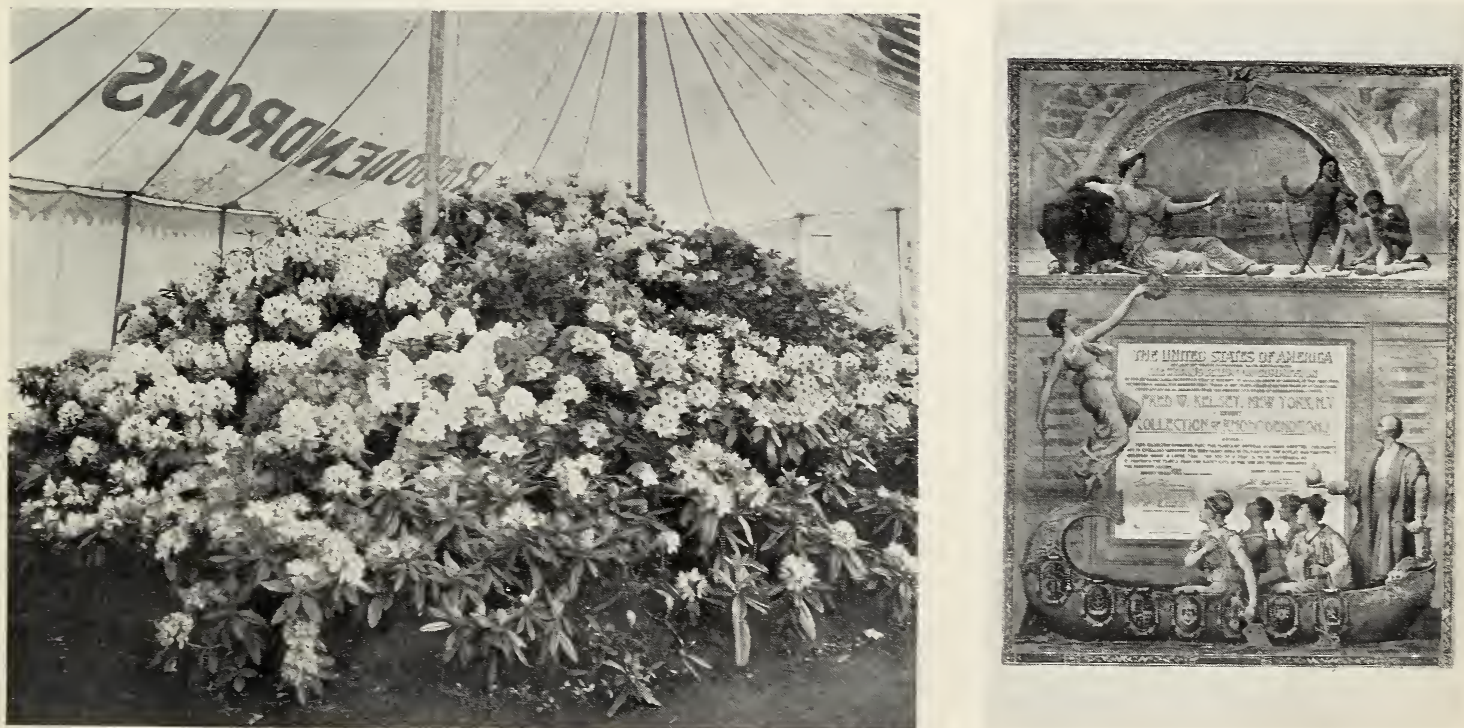

Rhododendrons have been among our specialties since 1878. The above pictures show our exhibit and Award of Merit at the World's Columbian Exhibition held at Chicago in 1893. 


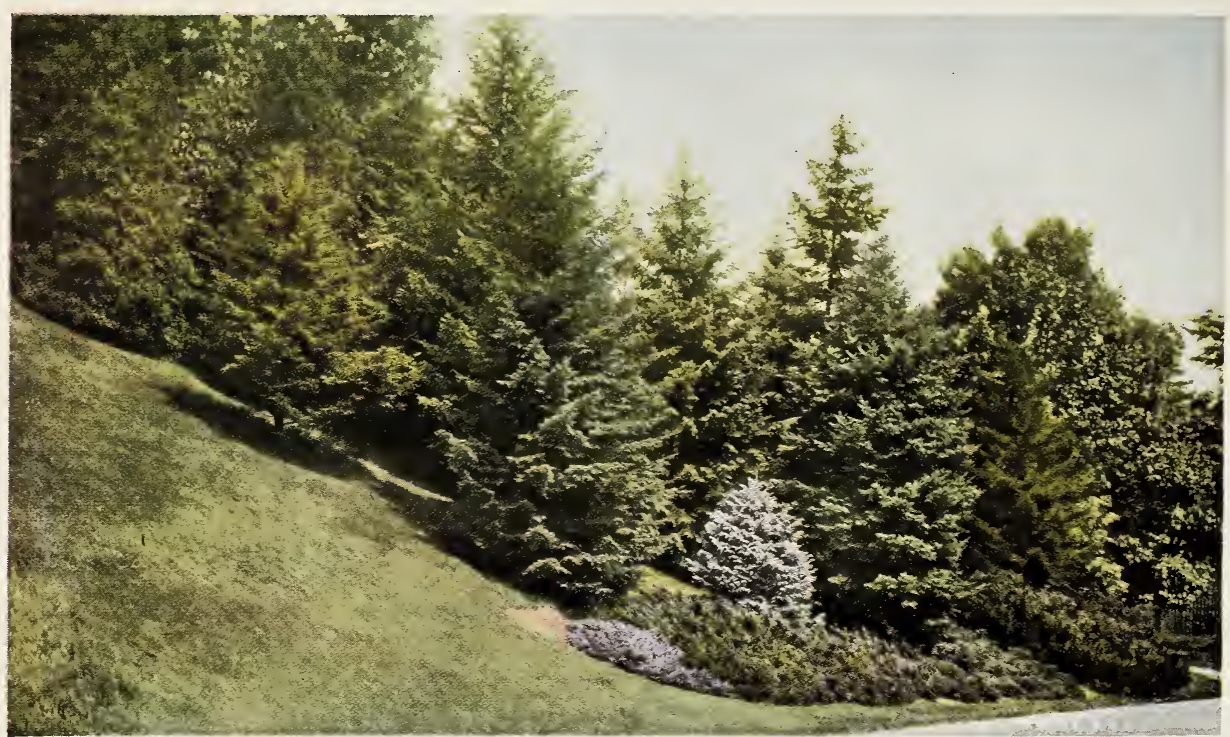

\section{EVERGREENS}

Evergreens, even rare varieties, are dependent for their value on two things - their root system and the shape of their tops. Root systems are thin or bushy depending on how many times the tree has been transplanted. We have some very inexpensive evergreens listed in the green list at the back of this book and also on page 7 . They are only once or twice transplanted and their growth has not been shaped and trained. The list below and on the following pages refers only to many times transplanted stock carefully grown and handled. Many sizes are not listed as well as many little known varieties for which the demand is small. However, we can furnish in all probability anything you want and will gladly quote prices on anything not here listed.

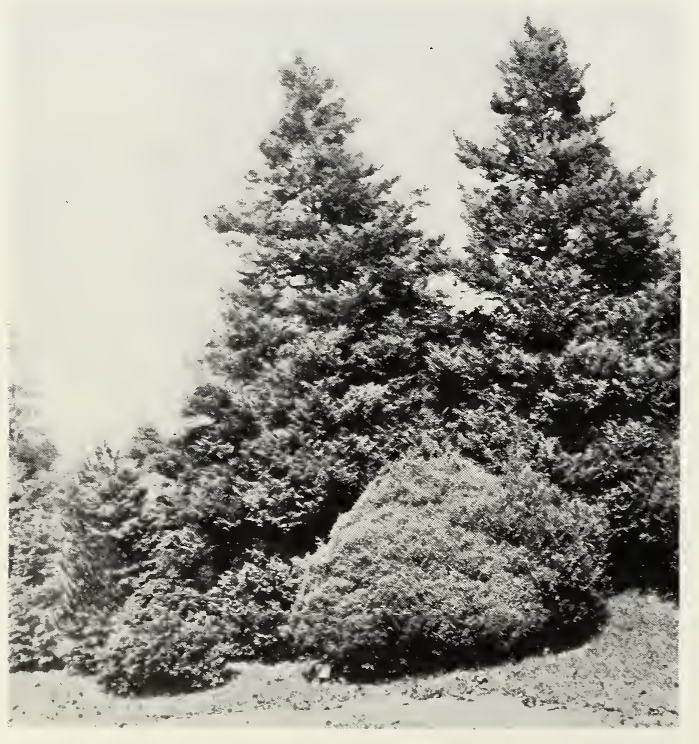

Retinospora group

\section{KEY TO NOTES}

Key letters following the name of each variety throughout this Price List refer to the table herewith. The figures following each name indicate ultimate height at maturity.

A-Profuse bloomer.

$\mathrm{B}-\mathrm{Flowers}$ very large.

C-Good for cut flowers.

D-Likes a light warm soil.

$\mathrm{E}$-Any good soil.

$\mathrm{F}$-Likes mois t ground.

$\mathrm{G}$-Slow growing.

$\mathrm{H}$-Rapid growing

I-Requires protection first year.

$J$-Requires sheltered position.

K-Very hardy.

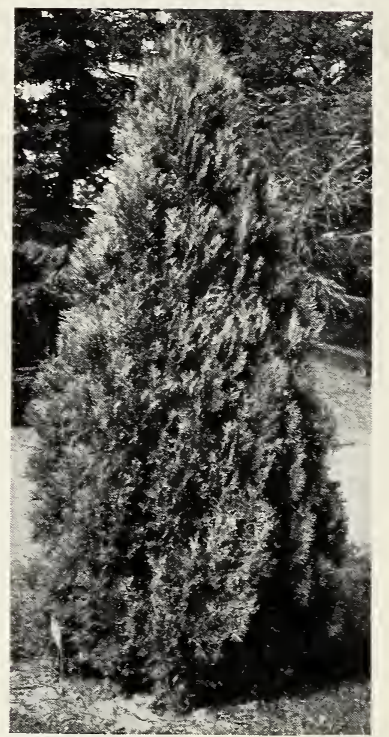

Thuya (Arbor vitae) Specimen

All Evergreens many times transplanted, balled and burlapped at these prices.

ARBOR VITAE (Thuya)

AMERICAN ARBOR VITAE (T. Occidentalis)-

EHK-15 to 20 feet. Narrow

pyramidal tree with dark green foliage.

1s to 24 inches............ \$ $2.00 \$ 17.00 \$ 150.00$

2 to 3 feet........... $3.00 \quad 25.00 \quad 190.00$

3 to 4 feet. . . . . . . . . . 5.50 $40.00 \quad 325.00$

4 to 5 feet............ $7.00 \quad 70.00 \quad 650.00$

5 to 6 feet............. $11.00 \quad 95.00$

6 to 7 feet............ $12.50 \quad 110.00$ 
COMPACT ARBOR VITAE

(T. Compacta)-EHK-t to 6 feet. A rery compact form of Siberian.

12 to 15 inches.

15 to 15 inches

18 to 24 inches

HOVEY'S ARBOR VITAE (T. Hoveyi - $\mathrm{EHK}-3$ to 4 feet-olobe form and bright green foliage.

12 to 15 inches.

15 to 18 inches

15 to 24 inches.

(Each) (10)

$\$ 2.00 \$ 20.00 \$ 140.00$

$\begin{array}{lll}2.50 & 24.00 & 185.00\end{array}$

$\begin{array}{lll}3.00 & 27.00 & 225.00\end{array}$

GOLDEN DWARF ARBOR

VITAE-Golden dwarf form of

Thuya Orientalis.

12 to 15 inches.

$\begin{array}{lll}3.50 & 30.00 & 250.00\end{array}$

15 to 18 inches

$\begin{array}{lll}4.50 & 39.00 & 300.00\end{array}$

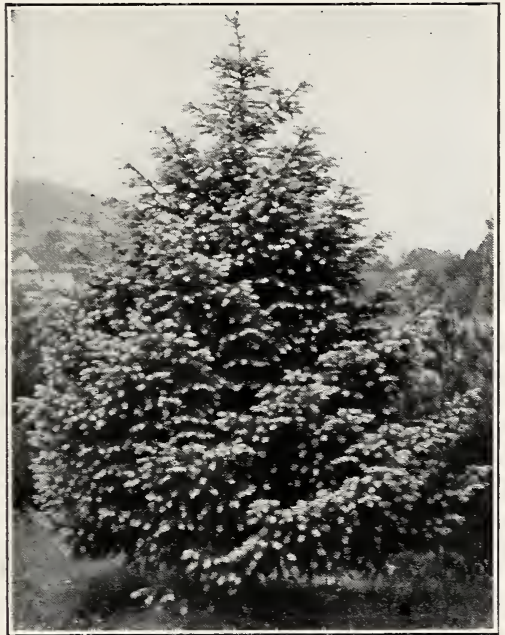

Douglas Fir Specimen
PEABODY ARBOR VITAE

(T. Lutea)-EGK-10 to 15

feet. Bright golden pyramid form.

15 to 18 inches

18 to 24 inches.

2 to 3 feet.

PYRAMIDAL ARBOR VITAE

(T. Occ. Pyramidalis)-EHK

-10 to 15 feet. Light green foli-

age. Very hardy and narrow in growth.

18 to 24 inches.

2 to $21 / 2$ feet.

3 to 4 feet.

SIBERIAN ARBOR VITAE

(T. Warreana) $-\mathrm{EHK}-10$ to

15 feet. Heary blue-green foliage.

12 to 15 inches.

15 to 18 inches

18 to 24 inches.

2 to 3 feet.

(Each) (10)

$\$ 2.00 \$ 18.00$

$3.00 \quad 27.00 \quad \$ 240.00$

$4.00 \quad 30.00$

$30.00-\ldots$.

VERVAENE'S ARBOR VITAE

-EHK-Fine dense dwarf with golden foliage.

is to 24 inches.

2 to $21 / 2$ feet.

$21 / 2$ to 3 feet
3 to 4 feet.

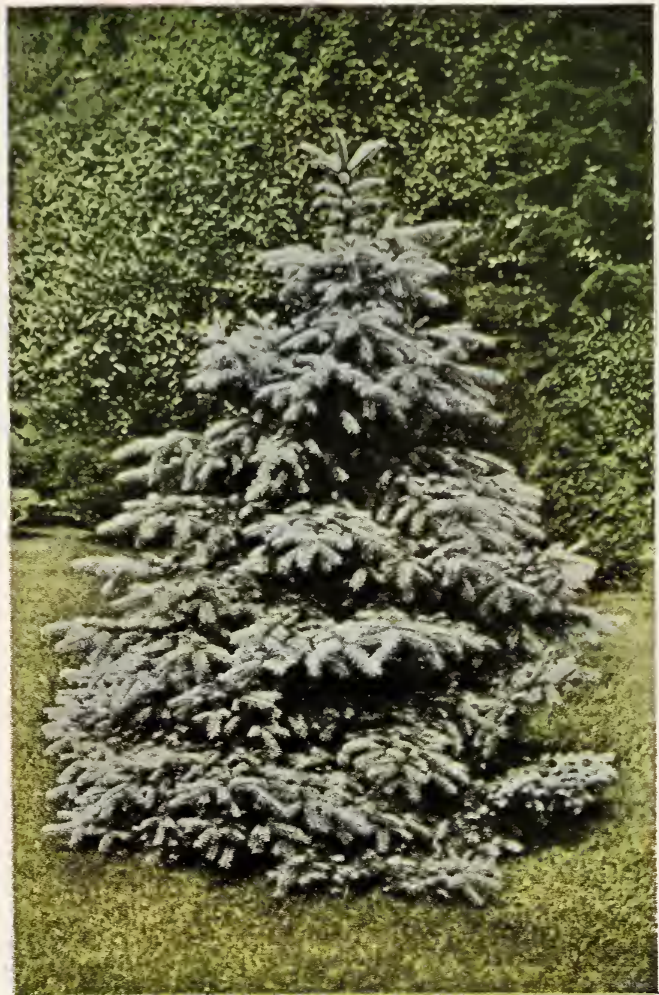

Colorado Blue Spruce

GYPRESS (Retinospora)

PLUMED JAPANESE CYPRESS

(R. Plumosa)-EIK-15 feet.

Dense delicate foliage light green

$$
\text { (Each) (10) (100) }
$$

12 to 15 inches

$\$ 2.00 \$ 17.50 \$ 145.00$

15 to 18 inches.

$\begin{array}{lll}2.50 & 22.00 & 190.00\end{array}$

18 to 24 inches

$\begin{array}{lll}3.00 & 27.00 & 240.00\end{array}$

2 to $2 \frac{1}{2}$ feet.

$4.00 \quad 38.00 \quad 350.00$

$21 / 2$ to 3 feet

$\begin{array}{lll}5.50 & 53.00 \quad 475.00\end{array}$

3 to 4 feet

$7.50 \quad 70.00$

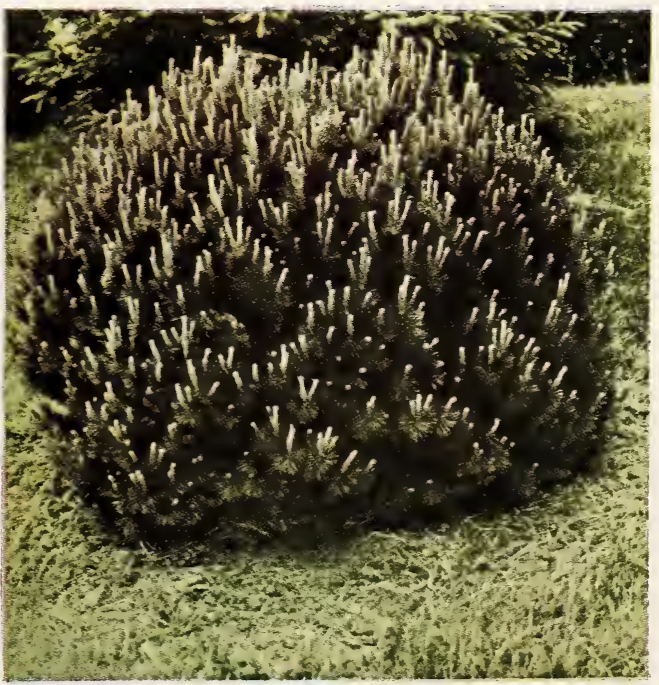

Mugho Dwarf Pine 


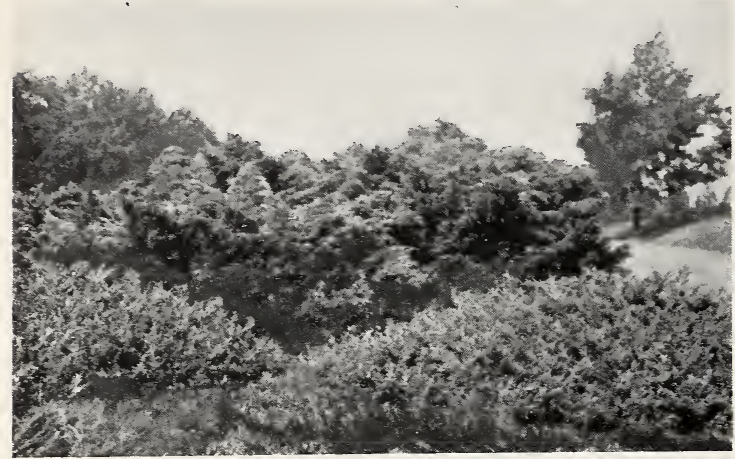

Group of Prostrate Juniper with Pfitzer Juniper in rear

\section{GOLDEN PLUMED CYPRESS}

(R. P1. Aurea)-EIK-15 feet-

Golden tipped branches.

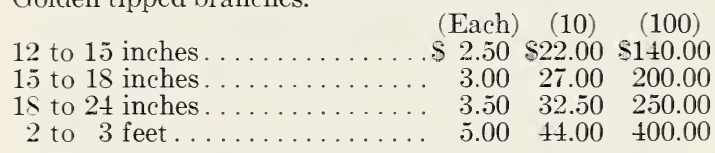

\section{THREAD-BRANCHED CYPRESS}

R. Filifera)-EK-10 to 15

feet. Stringlike, drooping foliage, good color.

15 to 18 inches.

18 to 24 inches.

$\begin{array}{lll}3.00 & 27.50 & 250.00\end{array}$

2 to 3 feet.

$4.00 \quad 35.00$

5.00

\section{GOLDEN THREAD BRANCHED}

\section{CYPRESS (R. Filifera Aurea)-}

EGK -4 to 6 feet. Dwarf golden form of above.

12 to 15 inches.

15 to 18 inches.

$35.00 \quad 300.00$

18 to 24 inches

4.50

$7.50 \quad 70.00$

SAWARA CYPRESS (R. Pisifera)-EHK-15 feet. Dense bluish foliage-pyramid shape.

$\begin{array}{rlrrr}15 \text { to } 18 \text { inches } \ldots \ldots \ldots \ldots \ldots \ldots & 2.50 & 20.00 & 150.00 \\ 18 \text { to } 24 \text { inches } \ldots \ldots \ldots \ldots \ldots \ldots & 3.00 & 25.00 & 200.00 \\ 2 \text { to } 21 / 2 \text { feet } \ldots \ldots \ldots \ldots \ldots \ldots & 4.00 & 37.50 & 300.00 \\ 3 \text { to } t \quad \text { feet } \ldots \ldots \ldots \ldots \ldots \ldots & 7.50 & 60.00 & 500.00\end{array}$

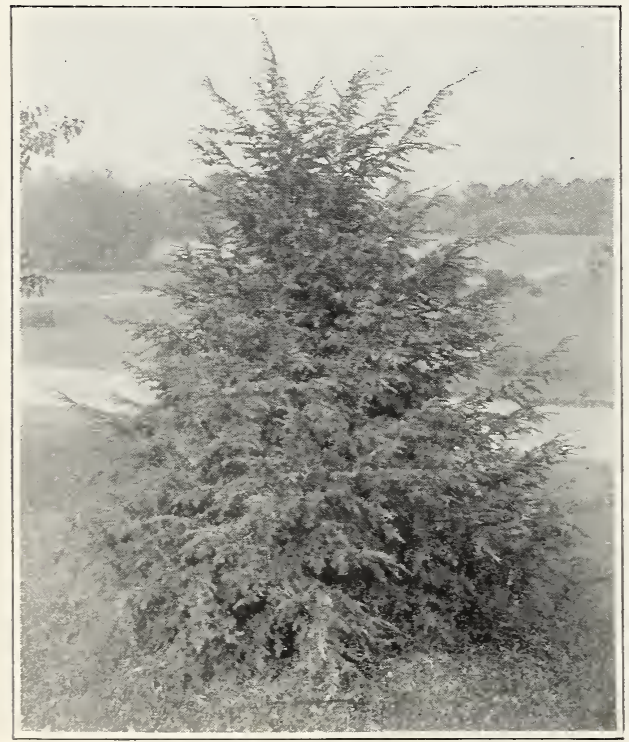

American Hemlock-fine specimen
GOLDEN SAWARA CYPRESS

(R. Obtusa Aurea). Golden form of above.

15 to 18 inches.

(Ea.) (10) (100)

$\$ 2.75 \$ 20.00 \$ 150.00$

18 to 24 inches. . . . . . $3.50 \quad 30.00 \quad 200.00$

2 to $21 / 2$ feet . . . . . . . . . $5.00 \quad 35.00 \quad 300.00$

$21 / 2$ to 3 feet............ $6.00 \quad 40.00 \quad 350.00$

3 to 4 feet........... $7.00 \quad 60.00 \quad \ldots$.

\section{VEITCH'S SILVER CYPRESS}

(R. Squarrosa)-EGIJ-10 to 15

feet. Pyramidal and dense with silvery feathery foliage - a beautiful tree.

12 to 15 inches.............

15 to 18 inches

18 to 24 inches.

2 to 3 feet.

$\begin{array}{lll}2.00 & 17.00 & 150.00\end{array}$

$\begin{array}{lll}2.50 & 23.00 & 200.00\end{array}$

$\begin{array}{lll}3.50 & 32.50 & 300.00\end{array}$

$5.00 \quad 47.50 \quad 400.00$

$8.0075 .00 \quad \ldots .$.

FIRS (Abies)

BALSAM FIR (Abies Balsamea) -FHK-50 to 60 feet broad, regular and pyramidal. Sweet scented needles.

18 to 24 inches

DOUGLAS FIR (A. Douglassi)

-EHK-40 to 50 feet-compact dense foliage of dark green.

12 to 15 inches.

18 to 24 inches

2 to 3 feet

4 to 5 feet

5 to 6 feet

$13.00 \quad 115.00$

$25.00 \quad 175.00$

$30.00 \quad 200.00$

$\begin{array}{ccc}7.00 & 60.00 & 450.00\end{array}$

$8.00 \quad 75.00 \quad 650.00$

SILVER FIR (A Concolor)EHK - 40 to 50 feet-foliage steel blue to silver-dense conical shape.

18 to 24 inches.

2 to 3 feet

5.00

40.00

375.00

3 to 4 feet

6.00

4 to 5 feet

$10.00 \quad 95.00$

900.00

5 to 6 feet

13.00125 .00

16.00155 .00

HEMLOCK (Tsuga)

CANADIAN HEMLOGK ('T. Canadensis - FHIJ-60 to 70

feet. Branches spreading and drooping. Stands shearing. Shade enduring.

12 to 15 inches.

15 to 18 inches.

18 to 24 inches

2 to 3 feet.

3 to 4 feet.

$19.00 \quad 145.00$

$20.00 \quad 150.00$

$\begin{array}{lll}4.00 & 35.00 \quad 250.00\end{array}$

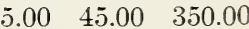

$\begin{array}{lll}5.00 & 70.00 \quad 600.00\end{array}$

\section{JUNIPERS (Juniperus)}

BLUE CEDAR (J. Virgin. Glauca)-EHK-15 to 20 feet. Silver gray foliage-rigorous.

$21 / 2$ to 3 feet............ 3 to $31 / 2$ feet. . . . . . . . . . $31 / 2$ to $t$ feet.

$6.00 \quad 5 \div .50 \quad 525.00$

$8.00 \quad 7 \% .50 \quad 690.00$

$9.50 \quad 90.00 \quad \ldots \ldots$

GROUND JUNIPER (J. Communis Canadensis)-EGK-3 to 4 feet. Gray green foliage and spreading to 10 feet or more. Useful to cover banks or rocks.

12 to 15 inches.

15 to 18 inches.

18 to 24 inches

2 to 3 feet.

$\begin{array}{lll}2.00 & 15.00 & 140.00\end{array}$

$\begin{array}{lll}3.00 & 25.00 & 190.00\end{array}$

$\begin{array}{lll}3.50 & 30.00 & 260.00\end{array}$

$\begin{array}{lll}4.00 & 35.00 \quad 290.00\end{array}$

\section{COMMON GOLDEN JUNIPER}

(J. Canadensis Aurea)-EGK3 to 4 feet. Dwarf spreading, fine golden color. 
GREEK JUNIPER (J. Excelsa Stricta)-EGK-6 to 10 feet. A fine, dense, narrow column of pleasing color and texture.

\$2.\$0 $\$ 26.00$

15 to 18 inches . . . . . . . . . $4.00 \quad 32.00$

1s to 24 inches. . . . . . . . . . . $5.00 \quad 45.00$

\section{IRISH JUNIPER (J. Hibernica)}

- EHJ $-S$ to 10 feet. A dense narrow column with light green foliage.

15 to 18 inches. .

18 to 24 inches.

$\begin{array}{rrr}1.00 & 9.00 \quad \$ 80.00\end{array}$ $1.50 \quad 13.00$

PFITZER'S JUNIPER (J. Pfitzeriana)-EGK -4 to 5 feet. Vase shaped spreading foliage, soft green. Thrives under city conditions.

12 to $1 \tilde{\text { inches. }}$

15 to 18 inches.

18 to 24 inches.

2 to 3 feet.

PROSTRATE JUNIPER (J. Sabina Prostrata)-EHK-18 to 24 inches high -4 to 8 foot spread.

12 to 15 inches.

15 to 18 inches.

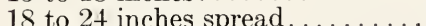

2 to 3 feet spread.

$\begin{array}{llr}1.50 & 12.50 & 95.00\end{array}$

$2.00 \quad 18.00 \quad 145.00$

$2.50 \quad 20.00$

$3.00 \quad 25.00$

RED CEDAR (Juniperus Virginiana)-EHK-20 to 30 feet. Branches upright. Conical in growth. Foliage dark green.

3 to 4 feet................

4 to 5 feet. . . . . . . . . . . .

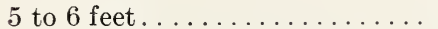

6 to 7 feet................

RED CEDAR (Cannarti Variety)

-12 to 15 feet.-Rich black green foliage. Dense.

18 to 24 inches. . . . . . . . . . . .

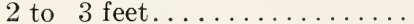

3 to 4 feet.

SABINE JUNIPER (J. Sabina) $-\mathrm{EHK}-4$ to $\tilde{\text { J feet. Irregular }}$ shape.

15 to 18 inches.............. 18 to 24 inches. . . . . . . . . . .

2 to 3 feet.

SWEDISH JUNIPER (J. Comm Suecica)-EHK - 7 to 8 feet. Like the Irish, but more bushy in growth.

12 to 15 inches............

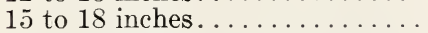

18 to 24 inches. . . . . . . . . . . .

2 to 3 feet.

TRIPARTITE JUNIPER (J. Tripartiti)-EHK-3 to 4 feet. A dwarf of irregular habit. Verv dense. Blue-gray in color. Very robust.

18 to 24 inches.

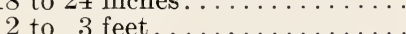

WAUKEGAN JUNIPER (J. Prostrata Douglassi) - EGK-1 to $1 \frac{1}{2}$ feet. Long trailing branches. Steel blue color, purple in winter.

12 to 15 inches . . . . . . . . .

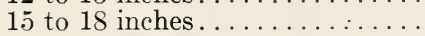

18 to 24 inches. . . . . . . . . . . $\begin{array}{lll}3.50 & 30.00 & 225.00\end{array}$

$\begin{array}{lll}4.00 & 33.00 & 300.00\end{array}$

$7.00 \quad 50.00 \quad \ldots \ldots$

$\begin{array}{lll}6.00 & 40.00 & \ldots \ldots\end{array}$

$\begin{array}{rrr}1.00 & 100.00 \quad 900.00\end{array}$

$\begin{array}{lll}3.50 & 130.00 & 1250.00\end{array}$

$5.00 \quad 45.00$

$6.00 \quad 50.00$

$9.00 \quad 80.00$

$\ldots$

....

$1.75 \quad 15.00$

$2.00 \quad 18.00$

$2.70 \quad 25.00$

$3.75 \quad 35.00$

200.00 290.00

$4.00 \quad 35.00$ $4.50 \quad 40.00$

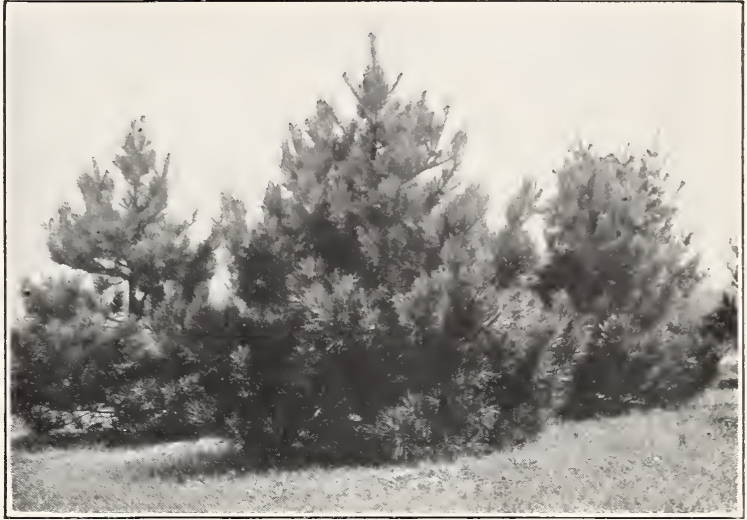

Red Pine (Pinus Resinosa)

\section{PINES (Pinus)}

AUSTRIAN PINE (Pinus Austriaca)-EHK-40 to 50 feet. The bushiest of the pines and fine for lawn specimen. Thrives near seashore.

12 to 18 inches.

18 to 24 inches.

2 to 3 feet.

3 to 4 feet

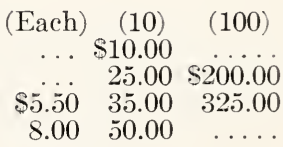

JAPANESE RED PINE (P. Densiflora)-EHK-40 to 50 feet. Long bright green needles. Good for seashore planting.

$\begin{array}{llllll}2 & \text { to } 21 / 2 \text { feet. } \ldots \ldots \ldots \ldots \ldots \ldots & 3.00 & 27.00 & 190.00 \\ 21 / 2 & \text { to } 3 & \text { feet. } \ldots \ldots \ldots \ldots \ldots \ldots & 3.75 & 35.00 & \ldots \ldots \\ 3 & \text { to } 4 & \text { feet. } \ldots \ldots \ldots \ldots \ldots & 5.50 & 52.50 & \ldots \ldots \\ 4 & \text { to } 5 & \text { feet } \ldots \ldots \ldots \ldots \ldots & 8.00 & \ldots & \ldots \ldots\end{array}$

\section{JAPANESE UMBRELLA PINE} (J. Dens. Tanyosho)-EGK-3 to 4 feet. Dwarf tree with flat table-top form.

18 to 24 inches........... $8.00 \quad 75.00$

2 to $2 \frac{1}{2}$ feet............. $10.00 \quad 85.00$

MUGHO PINE (Pinus Mughus) -EGK -6 to 8 feet. Dense, low, spreading growth, foliage bright green-two-inch needles.

$S$ to 10 inches (spread) . . . . . .

12 to 15 inches

$8.00 \quad 75.00$

15 to 18 inches.

$3.50 \quad 30.00 \quad 250.00$

$4.00 \quad 37.50$

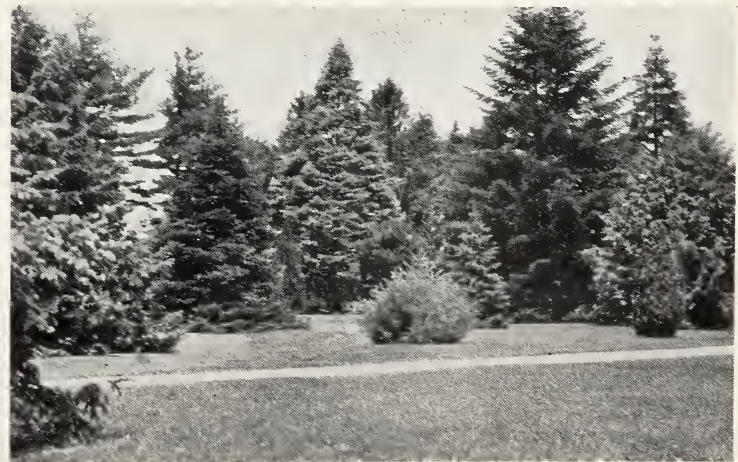

Spruces and Firs furnished by this company in 1897now magnificent specimens 
RED PINE (P. Resinosa)-EHK

-50 to 60 feet. Red bark, spreading branches. Very hardy and free from disease.

(Each) (10) (100)

$\$ 3.50 \$ 30.00 \$ 250.00$

2 to 3 feet

7.00

$\begin{array}{lll}11.00 \quad 95.00 & 850.00\end{array}$

SCOTCH PINE (P. Sylvestris)

-EHK -40 to 70 feet. Fast growing. Very hardy.

18 to 24 inches.............

2 to 3 feet...............

3 to 4 feet . . . . . . . . . .

$\begin{array}{llr}2.50 & 12.50 & 95.00\end{array}$

$\begin{array}{lll}3.50 & 25.00 & 190.00\end{array}$

$\begin{array}{lll}5.50 & 50.00 & 390.00\end{array}$

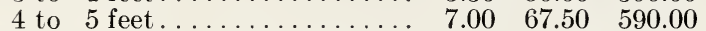

\section{SPRUCES (Picea)}

COLORADO BLUE SPRUCE

(P. Pungens Glauca)-Selected Blues-EGK-60 to 70 feet. Branches horizontal and densefoliage light blue.

12 to 18 inches..............

$\begin{array}{rrrr}18 \text { to } 24 \text { inches. . . . . . . . . . } & 8.00 & 60.00 \\ 2 \text { to } 3 \text { feet . . . . . . . . . . } & 9.50 & 90.00\end{array}$

3 to 4 feet .................... 13.50

(Larger sizes on request)

\section{COLORADO GREEN SPRUCE}

(P. Pungens). A very light green color. Otherwise same as above. 12 to 18 inches..............

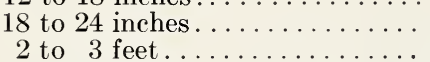

3 to 4 feet

$\begin{array}{lll}2.70 & 23.50 & 190.00\end{array}$

$\begin{array}{lll}4.00 & 37.00 & 325.00\end{array}$

$\begin{array}{lll}7.00 & 60.00 & 500.00\end{array}$

(Larger sizes on request)
3 to 4 feet

$6.00 \quad 55.00$

$\begin{array}{lllll}4 \text { to } 5 \text { feet } \ldots \ldots \ldots \ldots \ldots \ldots & 10.00 & 75.00 & 675.00\end{array}$

NORWAY SPRUCE (P. Excelsa)

-EHK-50 to 70 feet. Foliage dark shiny green, very hardy, spreading.

(Each) (10) (100)

12 to 18 inches............. $\$ 2.00 \$ 8.00 \$ 75.00$

18 to 24 inches.

2 to 3 feet

$\begin{array}{lll}2.75 & 16.00 & 135.00\end{array}$

3 to 4 feet

$\begin{array}{lll}3.50 & 25.00 & 195.00\end{array}$

PIGMY SPRUCE (P. Pygmea) -EGK - 6 feet. Light green foliage. Conical shape. Dense growth .

12 inch.

$6.00 \quad 50.00 \quad 425.00$

WHITE SPRUCE (P. Alba)-EHK -40 to 60 feet. Pyramidal and dense with medium green foliage.

12 to 18 inches . . . . . . . . . . . $1.50 \quad 12.00 \quad 95.00$

18 to 24 inches............ $1.75 \quad 16.00 \quad 135.00$

2 to 3 feet....................

3.00

YEWS (Taxus)-Endure Shade.

CANADIAN YEW (T. Canaden-

sis)-FGI-3 to 4 feet. A spreading low bush with crimson berries in winter.

12 to 15 inches . . . . . . . . . $2.00 \quad 16.00 \quad 130.00$

15 to 18 inches.

$2.75 \quad 24.00$

DWARF JAPANESE YEW ( $T$. Cuspidata Brevifolia)-EGK3 to 4 feet-black green foliage very dense. Absolutely hardy dwarf.

12 to 15 inches........... $4.00 \quad 35.00$

15 to 18 inches. . . . . . . . . . $5.50 \quad 45.00$

18 to 24 inches............ $8.00 \quad 70.00$

The remarkable photograph of Austrian Pine on the left shows one of our trees shortly after planting and in ordering specimens of this size and grade, the same sturdy growth and form and healthy condition may be relied on.
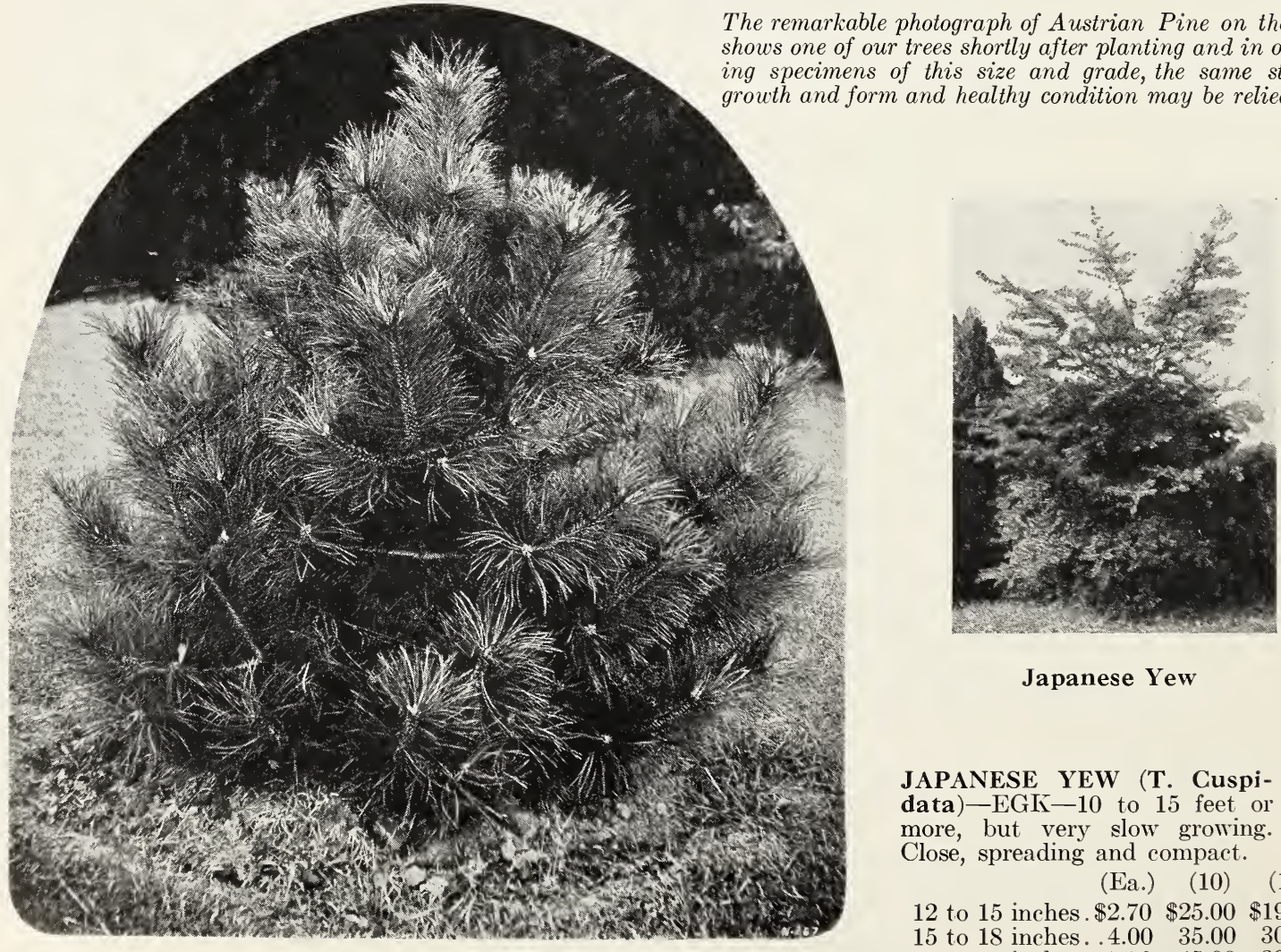

Japanese Yew

JAPANESE YEW (T. Cuspidata)-EGK-10 to 15 feet or more, but very slow growing. Close, spreading and compact.

$$
\text { (Ea.) (10) (100) }
$$

12 to 15 inches. $\$ 2.70 \$ 25.00 \$ 190.00$ 15 to 18 inches. . $4.00 \quad 35.00 \quad 300.00$ 18 to 24 inches. .5.50 $45.00 \quad 390.00$ 2 to 3 feet...8.00 $70.00 \quad \ldots \ldots$ 


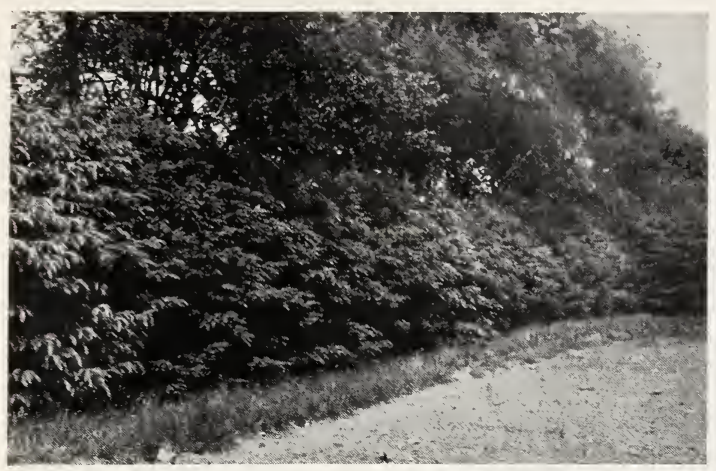

Hedge of Norway Spruce (White Spruce can be treated the same way). Sheared and dense

\section{HEDGES AND SCREENS}

It is not necessary to use specimen grades for mass planting, screens, hedges, etc. We have a special grade for this purpose in fine Nursery grown Evergreens-perfectly healthy and hardy and all twice or more times transplanted (except where noted)-These trees have good fibrous roots and are shipped without ball of earth, carefully packed in wet moss, unless otherwise requested.

ARBORVITAE (Thuya Occidentalis) (100) (1000)

10 to 12 in. (twice transplanted) . . . . \$20.00\$170.00

1 to $1 \frac{1 / 2}{2}$ feet (twice transplanted) . . $\quad 40.00 \quad 380.00$

$1 \frac{1}{2}$ to 2 feet (twice transplanted) . . . $80.00 \quad 650.00$

FIR Douglas (Pseudotsuga)

1 to $1 \frac{1}{2}$ feet (twice transplanted) . . . $35.00 \quad 270.00$ HEMLOCK (Tsuga canadensis)

10 to 12 in. (twice transplanted) . . . . $80.00 \quad 690.00$ 15 to 18 in. B. \& B. (shapely) ..... 150.00

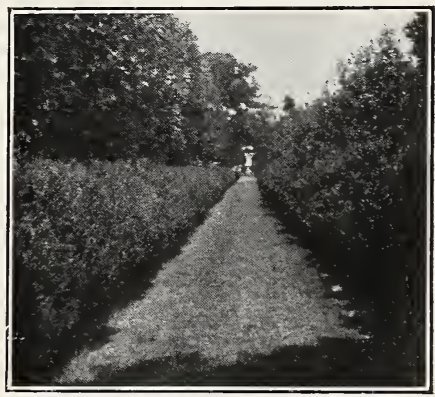

Boxwood hedge $-3 \mathrm{ft}$. high

\section{LARCH (Larix)}

L. Europea (European Larch). (Each)

3 to 4 feet B. \& B. (bushy).... \$4.00 350.00

L. Leptolepsis (Japanese Larch)

3 to 4 feet B. \& B......... 2.00175 .00

PINE (Pinus)

P. Nigra (Austrian)

10 to 12 in. (twice transplanted) . . . . $30.00 \quad 225.00$

6 to 14 in. (once transplanted) ........ $12.00 \quad 80.00$

P. Densiflora (Japanese Red Pine)

$15.00 \quad 80.00$

18 to 24 in. (once transplanted)..... 15.00

P. Banksiana (Jack Pine)

18 to 24 in. (twice transplanted). . . . 50.00

P. Thunbergii (Japanese Black Pine)

12 to 24 in. (once transplanted).......

P. Resinosa (Norway Red Pine)

8 to $12 \mathrm{in.} \mathrm{(once} \mathrm{transplanted)} \mathrm{(heavy)}$

14 to 20 in. (twice transplanted)......

P. Sylvestris (Scotch Pine)

12 to 18 in. (once transplanted) . . . $\quad 6.00 \quad 25.00$

10 to 24 in. 5 yr. (once transplanted) . . $\quad 8.00 \quad 40.00$

12 to 18 in. (twice transplanted) . . . . . $24.00 \quad 170.00$

18 to 24 in. (twice trasnplanted) . . . . $30.00 \quad 250.00$

4 to $5 \mathrm{ft}$. (thrice transplanted) $\ldots \ldots .375 .00 \quad \ldots \ldots$

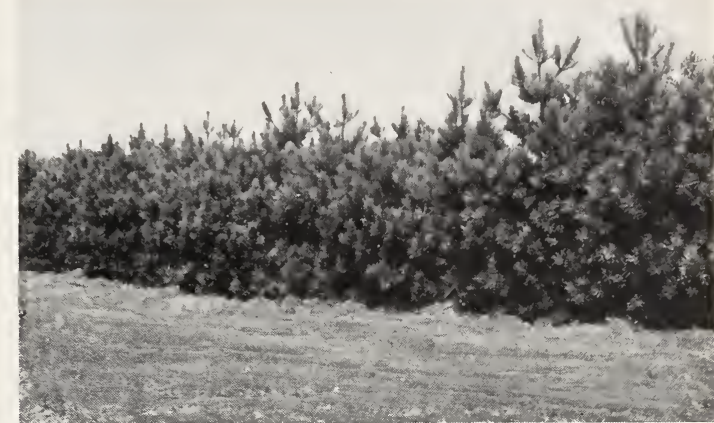

Red Pine Hedge-requires about $6 \mathrm{ft}$. width

SPRUCE (Picea)

P. Excelsa (Norway Spruce)

(100) $\quad(1000)$

8 to 12 in. (stocky) (twice transplanted) $\$ 10.00 \quad \$ 78.00$

12 to 18 in. (once transplanted) ....... $18.00 \quad 150.00$

12 to 18 in. (twice transplanted) . . . . $30.00 \quad 250.00$

18 to 24 in. (twice transplanted) . . . . $40.00 \quad 350.00$

P. Alba (White Spruce)

18 to 24 in. (twice transplanted) . . . . $60.00 \quad 500.00$

5 to $12 \mathrm{in.}$ (twice trans. stocky) … $10.00 \quad 78.00$

12 to 18 in. (twice transplanted) . . . $40.00 \quad 300.00$

\section{BARBERRY (Berberis)}

B. Thunbergii (Japanese)

18 to 24 in. (3 years transplanted)... $12.00 \quad 100.00$

\section{BOXWOOD (Buxus)}

BOXWOOD (Buxus Sempervirens)-

FGI -5 to 10 feet for specimens or hedges.

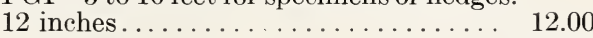

15 inches........... 20.00

2 feet.................. 40.00

$21 / 2$ feet. . . . . . . . . . . . . 60.00

95.00

125.00

BOX EDGING (Buxus Suffruticosa)

- EGI-4 to 8 feet.

6 to 8 inches..

8 to 10 inches.

6.25

7.50

50.00

67.50

\section{PRIVET (Ligustrum)}

CALIFORNIA PRIVET (L. Ovalifolium)-EHK-12 to 15 feet.

12 to 18 inches. .

(100) $\quad(1000$

2 to $3 \mathrm{ft} \ldots .$.

$4.00 \quad 30.00$

3 to 4 feet

$10.00 \quad 40.00$

4 to 5 feet (very heavy).

50.00

$20.03 \quad 150.00$

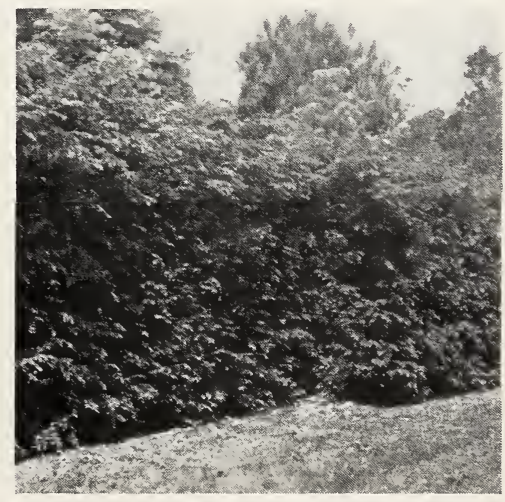

Dense, soft, impenetrable Hemlock 


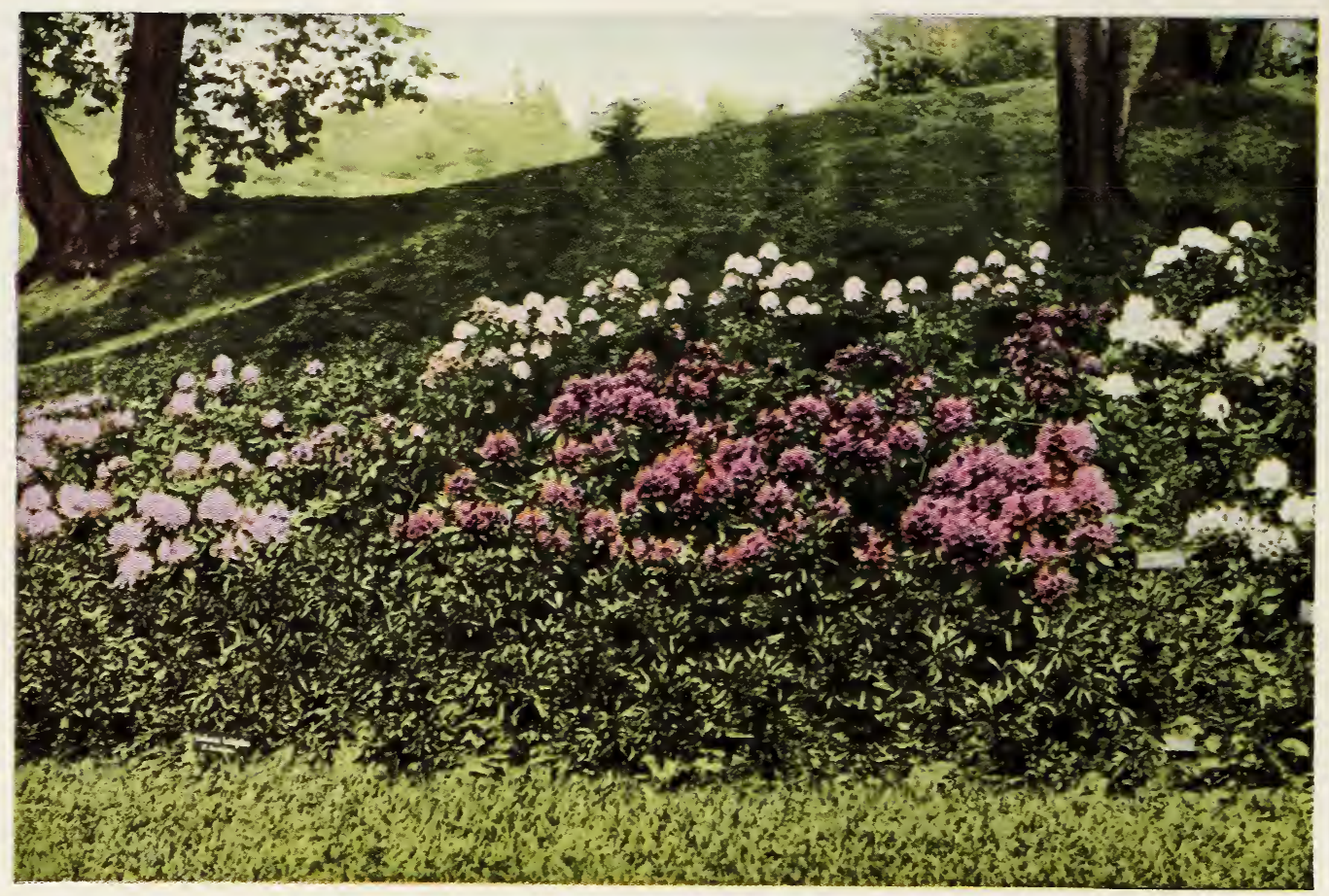

Hardy Hybrid Rhododendron in front, rose white blooms of the native Maximum show in the rear

RHODODENDRONS
(Shade-acid soil)
ONE of our specialties since 1878
has been furnishing native Rhododen-
drons in carlots. Our distribution
point is now not far from New York,
so that freight is comparatively in-
expensive.
Some of the finest estates in the
east have been furnished with Rhodo-
dendrons exclusively by this Com-
pany and we have been repeatedly
commended on the quality of our stock.

RHODODENDRON CAROLINA-FK

-8 to 10 feet. Fine native with light to

deep pink bloom in June.

(Each)

$\$ 2.75 \$ 20.50$

1 to $2 \mathrm{ft}$. clumps.

2 to $3 \mathrm{ft}$. clumps

3 to $4 \mathrm{ft}$. clumps

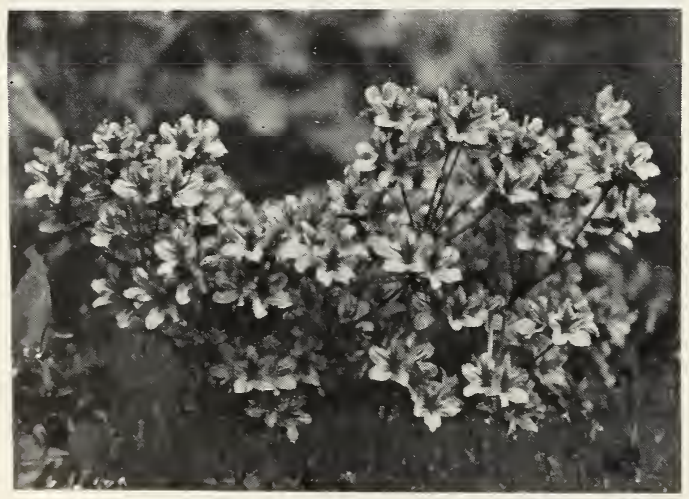

Azalea Hinodigiri 10 to 12 inches
RHODODENDRON GATAWBIENSE

-FK -6 to 8 feet. More compact than

the above-rosy purple bloom in June.

1 to $2 \mathrm{ft}$. clumps

(Each)

2 to $3 \mathrm{ft}$. clumps

$\$ 3.50$

$\$ 20.50$

3 to $4 \mathrm{ft}$. clumps

5.00

RHODODENDRON MAXIMUM-

FK -8 to 10 feet. Rose bloom in June and July. (See special offer on page 9.)

2 to $3 \mathrm{ft}$. clumps

3 to $4 \mathrm{ft}$. clumps

$\$ 4.00 \$ 13.00$

$5.00 \quad 17.50$

MOUNTAIN LAUREL (Kalmia Latifolia)-FK-j to 8 feet. Shapely bush covered with white to pink bloom in June - attractive buds in May.

18 to 30 inch clumps .

$\$ 2.50 \$ 12.00$

HARDY HYBRID RHODODENDRONS-FK-We offer the following fine varieties:

AMPHION-Large bloom, clear pink with white eve. Free flowering.

CATAWBIENSE ALBUM-White.

MRS. C. S. SARGENT-Deep rose shading to red. Large bloom.

15 to 18 inches.

$\$ 6.00 \$ 55.00$

15 to 24 inches.

$10.00 \quad 90.00$

\section{EVERGREEN SHRUBS}

ABELIA (A. Grandiflora) (Arbutus Bush)-AEHK-5 feet. White bell-shaped blooms in profusion over a period of about eleven weeks-June to September. Leaves rich bronze in winter.

12 to 18 inches.

18 to 24 inches.

(Each) (10) (100)

35.00 


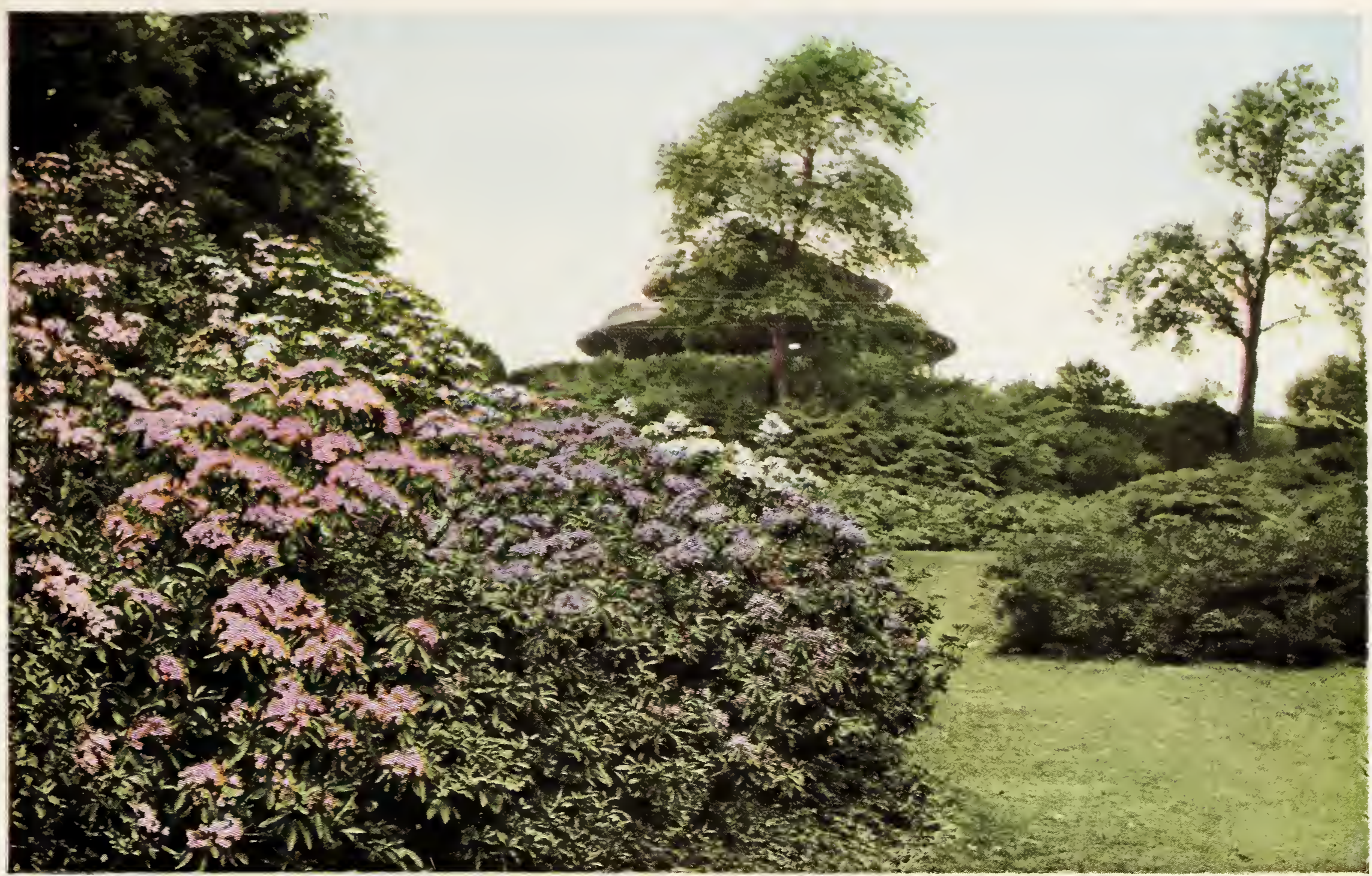

The pink and white Mountain Laurel (Kalmia) combine nicely both as to color and foliage with the purplish Rhododendron Catawbiense. Striking combinations of color are possible through a judicious use of the material offered on these pages.

AZALEA AMOENA (Lovely Azalea)-Similar to next - pink blooms.

4 to 6 inches.

6 to 8 inches

8 to 10 inches

10 to 12 inches.

12 to 15 inches.

AZALEA HINODIGIRI (Japanese Evergreen Azalea)-FK -2 to 3 feet. Brilliant crimson bloom completely covers bush in May-foliage rich bronze in winter. A superb variety. (Each)

4 to 6 inches. 1.20

6 to 8 inches.

$\begin{array}{llll}8 \text { to } 10 \text { inches. . . . . . . . . } & 2.50 & 18.00\end{array}$

10 to 12 inches......... $2.80 \quad 27.00$

DAPHNE GNEORUM (Garland

Flower)-AEK-12 to 15 inches.

One of the finest dwarf evergreen shrubs, covered with pink blooms in May, which continue sparsely through the summer, and a profusion of bloom again in September. Very fragrant. Forms a dense bush two feet or more across.

6 to 8 inches.

8 to 10 inches.

10 to 12 inches.

1.00

1.30

1.75

8.00

11.00

16.00

75.00

95.00

AMERICAN HOLLY (I. Opaca) -FGK-8 to 15 feet. Yellow flowers in June and scarlet berries in winter.

12 to 15 inches. .

18 inches

$2.00 \quad 16.00$

2 to 3 feet

$2.50 \quad 20.00$

3 to 4 feet.

$3.50 \quad 28.00$

(100)

75.00

245.00

\section{SPECIAL CARLOT OFFERS}

(Minimum Carload)

\section{RHODODENDRONS.}

$\begin{array}{lll}\text { R. Maximum } & 2-3 \mathrm{ft} \ldots \ldots \ldots 175 \text { clumps for } \$ 185.00 \\ & 3-4 \mathrm{ft} \ldots \ldots \ldots 150 \text { clumps for } & 215.00 \\ \text { R. Carolina } & 1-2 \mathrm{ft} \ldots \ldots \ldots .300 \text { clumps for } & 430.00 \\ & 2-3 \mathrm{ft} \ldots \ldots \ldots 200 \text { clumps for } & 490.00 \\ \text { R. Catawbiense } & 1-2 \mathrm{ft} \ldots \ldots \ldots .300 \text { clumps for } & 430.00 \\ & 2-3 \mathrm{ft} \ldots \ldots \ldots 200 \text { clumps for } & 490.00 \\ \text { Kalmia Latifolia } & 18-30 \text { inch . . 200 clumps for } & 180.00\end{array}$

Or we will mix cars, some of each, at proportionate prices and quantity. Above are minimum carloads, but can load these sizes up to 700 or even 1000 in a car safely.

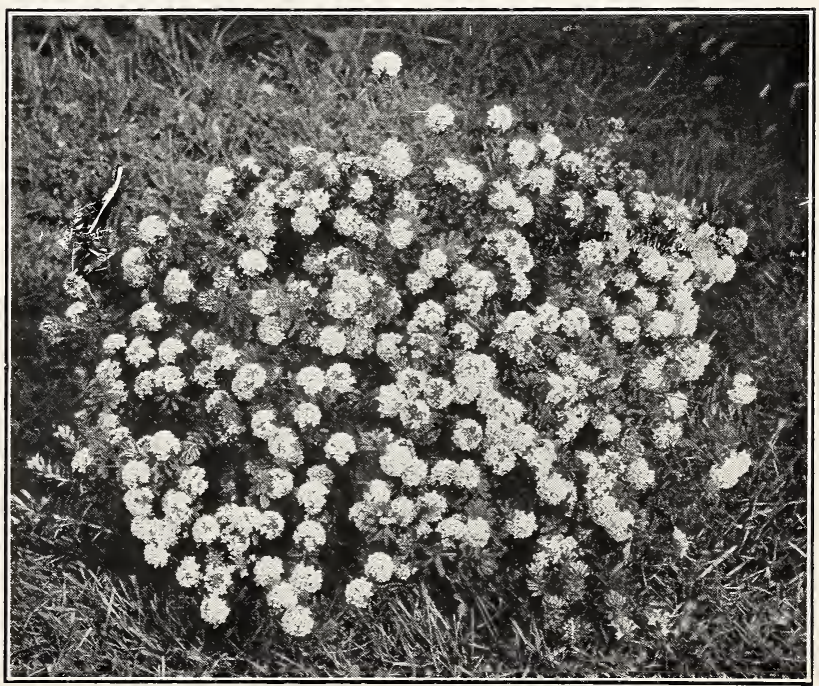

The Garland Flower (Daphne) 


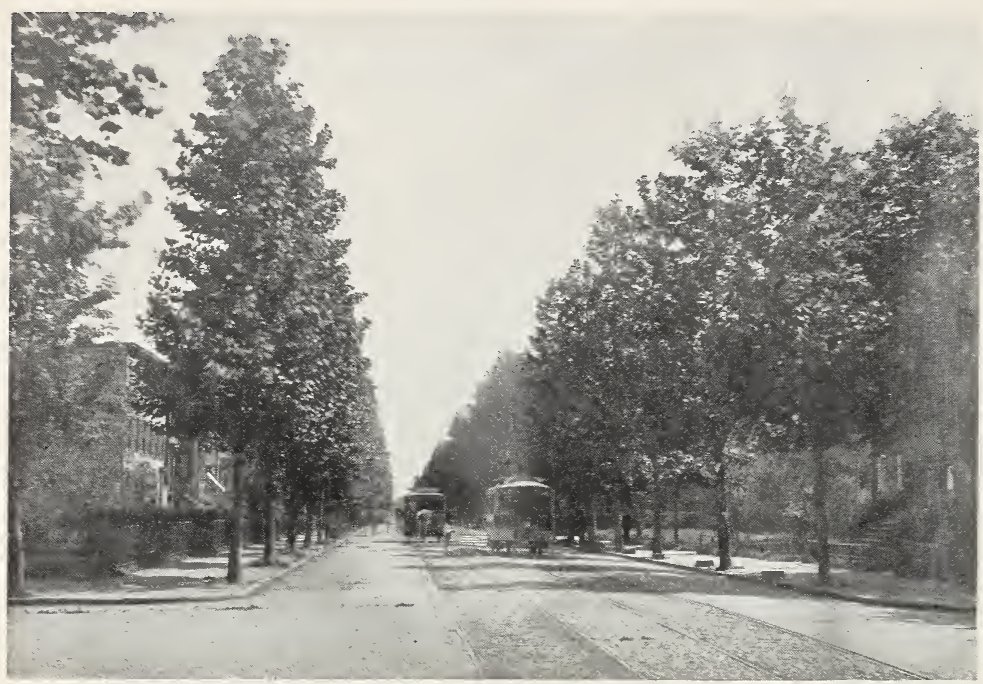

Note the Horse-cars. A street planting furnished in 1885 and photographed in the "Gay nineties."
MAPLE (Acer)

NORWAY MAPLE (A. Platanoides)-EGK-50 feet. Compact rounded top. One of the finest of street or a venue trees.

$$
\text { (Ea.) (10) (100) }
$$

6 to 8 feet $\$ 3.50 \$ 30.00 \$ 245.00$ 8 to 10 feet $4.00 \quad 35.00 \quad 295.00$ 10 to 12 feet $\quad 5.50 \quad 50.00 \quad 475.00$ $1 \frac{1}{2}$ to $13 / 4^{\prime \prime} \quad 7.00 \quad 60.00$ 2 to $2 \frac{1}{2^{\prime \prime}} 10.00 \quad 80.00$

SILVER MAPLE (A. Dasycarpum)-EHK-50 feet. Rapid grower and spreading. Popular avenue tree.

$\begin{array}{rrrrr}6 \text { to } \delta^{\prime} & \ldots & 1.50 & 10.00 & 70.00 \\ 8 \text { to } 10^{\prime} & \ldots & 2.00 & 14.00 & 90.00 \\ 10 \text { to } 12^{\prime}\left(11 / 2^{\prime \prime}\right) & 4.00 & 25.00 & 175.00 \\ 13 / 4 \text { to } 2^{\prime \prime} & 5.00 & 30.00 & 225.00 \\ 2 \text { to } 21 / 2^{\prime \prime} & 6.00 & 50.00 & 275.00\end{array}$

\section{ELM (Ulmus)}

AMERICAN ELM (U. Americana)-EHK-60 to 80 feet. Easily the finest native tree, for street or park.

$$
\begin{array}{rrr}
\text { (Each) } & (10) & (100) \\
\$ 2.00 & \$ 15.00 & \$ 70.00 \\
3.00 & 20.00 & 145.00 \\
5.00 & 45.00 & 245.00 \\
7.00 & 55.00 & 255.00 \\
\ldots & \ldots & 295.00
\end{array}
$$$$
6 \text { to } 8 \text { feet }
$$$$
8 \text { to } 10 \text { feet }\left(1 \frac{1}{4} \text { inches }\right) \text {. }
$$$$
1 \frac{1}{2} \text { to } 13 / 4 \text { inches . }
$$$$
13 / 4 \text { to } 2 \text { inches }
$$$$
2 \text { to } 2 \frac{1}{2} \text { inches. }
$$

\section{LINDEN (Tilia)}

AMERICAN LINDEN (T. Americana)-EHK- 50 to 60 feet. Stately tree with large smooth leaves. Fine street shade.
6 to 8 feet
$5.00 \quad 15.00 \quad 145.00$
8 to 10 feet
$1 \frac{1}{2}$ to 2 inches
$\begin{array}{lll}6.00 & 30.00 & 200.00\end{array}$
3 to 4 inches.
$\begin{array}{lll}7.50 & 55.00 & 300.00\end{array}$
$12.50 \quad 90.00$

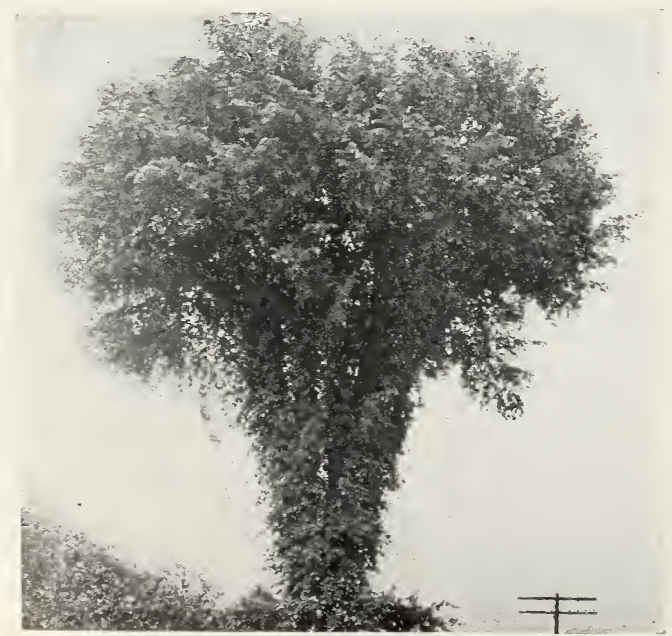

Specimen American E1m
SUGAR MAPLE (Acer Sacharinum)-EHK-40 to 60 feet. Upright dense growth. Leaves vellow and crimson in Autumn. Excellent for street.

6 to 8 feet.............. $3.00 \quad 25.00$

8 to 10 feet. . . . . . . . . . . 3.5030 .00

10 to 12 feet $. .50-5.50$

$11 / 2$ to 2 inches

2 to 3 inches.

$\begin{array}{lll}6.00 & 55.00 & 300.00\end{array}$

$\begin{array}{lll}14.00 & 85.00 & 495.00\end{array}$

\section{OAK (Quercus)}

PIN OAK (Q. Palustris)-FHK 40 to 60 feet. A favorite avenue tree. Crimson leaves in Autumn.

8 to 10 feet. .

RED OAK (Q. Rubrum)-EHK -50 to 75 feet. One of the few oaks to drop its leaves in early winter.

4 to 6 feet.

6 to 8 feet

8 to 10 feet $\left(1 \frac{1}{4} /\right.$ inches $)$.

$11 / 2$ inches caliper

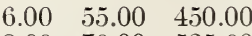
$8.00 \quad 70.00 \quad 525.00$

PLANE (Platanus)

ORIENTAL PLANE (P. Orientalis)-EFHK-50 to 60 feet. Creamy white bark mottled with dark blotches.

5 to 6 feet.

6 to 8 feet.

8 to 10 feet.

10 to 12 feet

$11 / 2$ to 2 inches

\section{2 to $21 / 2$ inches.}

SYGAMORE (P. Occidentalis) -FHK- j0 to 60 feet. Similar to the above with slightly larger leaves. Excellent for street or park.

6 to 8 feet

$S$ to 10 feet.

$1 \frac{1}{2}$ to $13 / 4$ inches

$13 \frac{1}{4}$ to 2 inches

POPLAR (Populus)

LOMBARDY POPLAR (P. Fastigia ta)-EHK-40 to 50 feet. Narrow, compact and picturesque. Of extremely rapid growth.

8 to 10 feet. . . . . . . . . . $1.50 \quad 6.00 \quad 50.00$ 10 to 12 feet................

12 to 14 feet . . . . . . . . . . $2.50 \quad 10.00 \quad 95.00$ 


\section{ORNAMENTAL TREES}

As A GENERAL RULE flowering and lawn trees are not so tall growing as those listed on the last page under "Deciduous Trees." They are fine either in the open or to break the monotony of a shrubbery border.

\section{BEECH (Fagus)}

AMERICAN BEECH (F. Americana)-EGK-50 to 60 feet.

Smooth silver grey bark. Dense round head.

$$
\begin{array}{lr}
(\text { Each }) & (10) \\
(100) & (100)
\end{array}
$$

3 to 4 feet

RIVER'S PURPLE BEECH $(F$. Riversii)-EGI-50 to $60 \mathrm{ft}$. A beautiful tree holding its color throughout the summer (See illustration in natural color). $\begin{array}{rrr}12 \text { to } 14 \text { feet specimens. . . . . . \$30.00 } & 250.00 \\ 14 \text { to } 16 \text { feet specimens . } & 40.00 & 350.00\end{array}$

(We have trucking and balling facilities near New York City, if required.)

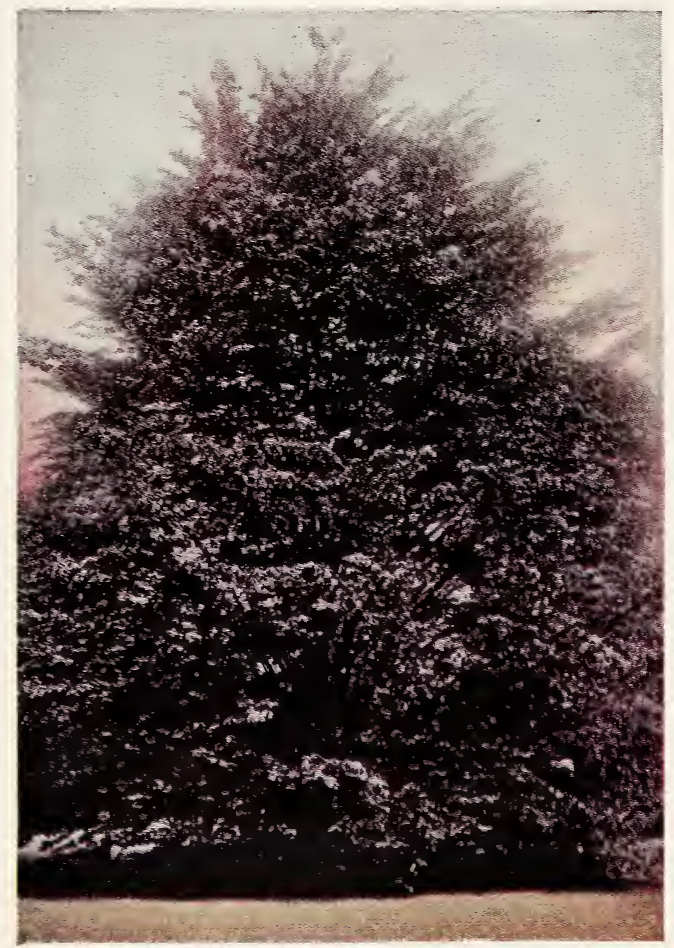

River's Purple Beech

CHERRY (Cerasus)

JAPANESE FLOWERING

CHERRIES-Small tree-EAG

-These are among the first things

to flower in spring and extremely

choice and scarce.

JAPANESE WEEPING CHERR Y

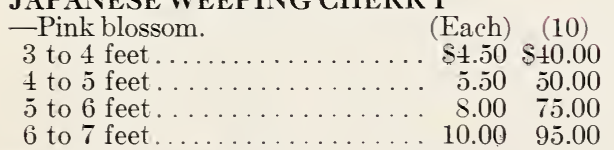

(100)

WHITE FLOWERING JAP-

\section{ANESE CHERRY}

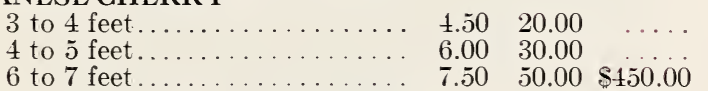

PINK FLOWERING JAPANESE

CHERRY

6 to 7 feet

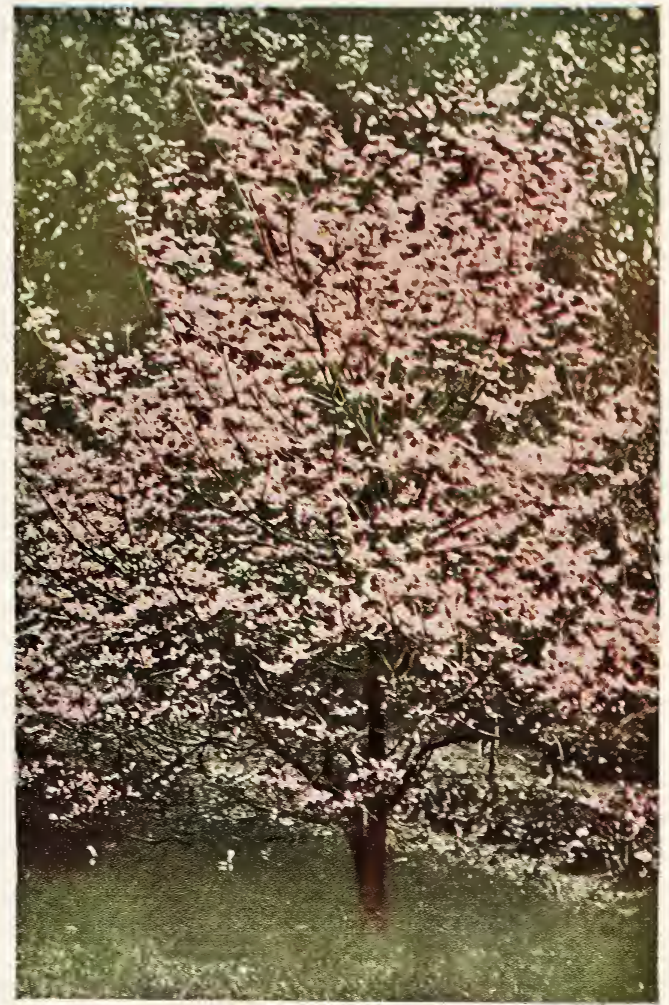

Red Flowering Dogwood

DOGWOOD (Cornus)

WHITE FLOWERING DOG-

WOOD (C. Florida)-DIJ-20

feet. Covered with white blooms

in May. Crimson leaves and berries in Autumn.

2 to 3 feet.

3 to 4 feet

6 to 8 feet

8 to 10 feet

10 to 12 feet.

RED FLOWERING DOGWOOD

(Each) (10) (100)

$\$ 1.50 \$ 12.00 \$ 75.00$

$\begin{array}{lll}2.00 & 18.00 & 150.00\end{array}$

$3.50 \quad 30.00$

$6.00 \quad 40.00$

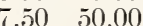

(See photo)

Same as above with pink blooms.

18 to 24 inches.

2 to 3 feet

3 to 4 feet

MAGNOLIA

Umbrella Magnolia (M. Tripetela)-FHI-30 to 40 feet. Long leaves and large white flowers in May.

2 to 3 feet

5 to 6 feet

6 to 8 feet

8 to 10 feet

MAPLE (Acer)

BLOODLEAF JAPANESE

MAPLE (A. Palmatum Atropurpurea)-EGI-10 to 15 feet.

Dense in growth and makes a fine specimen. Leaves bloodred.

12 to 18 inches (grafted).

$3.50 \quad 30.00$

$12.00 \quad 95.00$

$\begin{array}{lll}3.00 & 24.00 & 195.00\end{array}$

$4.00 \quad 32.00 \quad 245.00$

$\begin{array}{lll}6.00 & 50.00 & 295.00\end{array}$

WILLOW (Salix)

WEEPING WILLOW (S. Baby-

lonica)-FHIJ-30 to 40 feet.

Gray pendulous branches. Attractive near water.

$\begin{array}{rrrrr}6 \text { to } 8 \text { feet } \ldots \ldots \ldots \ldots \ldots \ldots \ldots & 1.75 & 10.00 & 80.00 \\ 8 \text { to } 10 \text { feet } \ldots \ldots \ldots \ldots \ldots \ldots & 2.75 & 12.50 & 100.00 \\ 10 \text { to } 12 \text { feet } \ldots \ldots \ldots \ldots \ldots \ldots & 3.50 & 16.50 & 125.00\end{array}$

IN spite of a general shortage of good varieties, we can

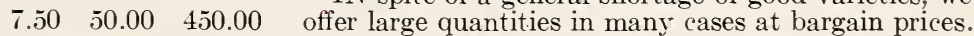




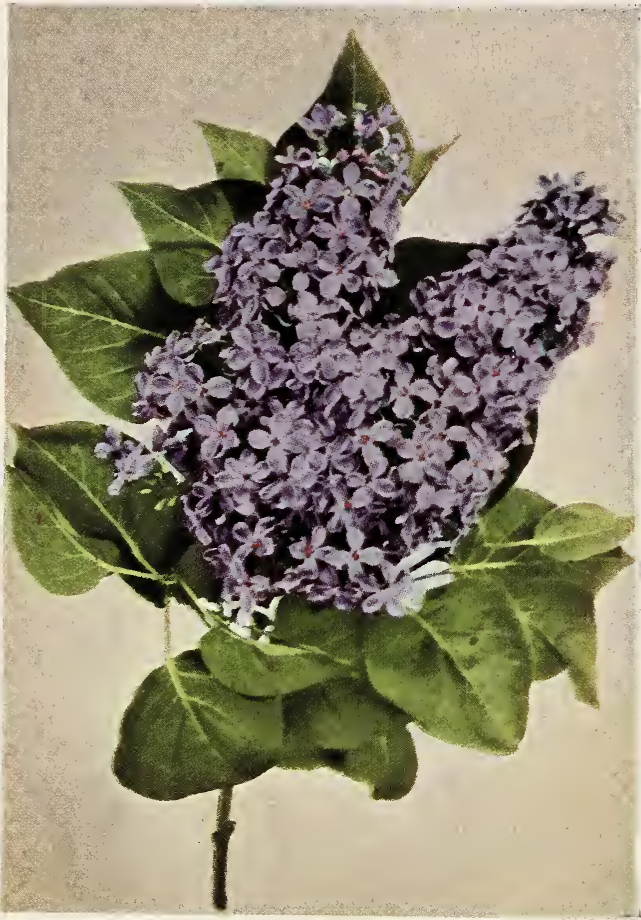

Lilac

The list of Deciduous Flowering Shrubsis arranged, as to standard varieties, on the next page. Prices are given per 10 -but special prices will be gladly quoted on these or other varieties in quantity.

\section{AZALEAS}

AZALEA MOLLIS (Lovely

Azalea)-FGK-May. Ranges from light pink to rich yellow and red.

12 to 15 inches

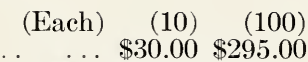

15 to 18 inches $\mathrm{B}$. \& B $\$ 4.00 \quad 35.00$

AZALEA ARBORESCENS-

Large white bloom in July, fragrant.

12 to 15 inches B. \& B.

$2.00 \quad 18.00$

15 to 18 inches B. \& B.

$3.00 \quad 25.00 \quad 240.00$

A. CALENDULACEA-Flame colored in June.

$\begin{array}{lllll}1 \text { to } 2 \text { feet (clumps) B. \& B . . . } & 2.00 & 12.00 & 95.00\end{array}$ 2 to 3 feet (clumps) B. \& B . . . $2.50 \quad 2.00000$ A. CANESCENS (Rosea)-Similar to Vaseyi.

18 to 24 inches B. \& B.

$\begin{array}{lll}1.50 & 12.00 \quad 95.00\end{array}$

A. NUDIFLORA (Pinkster)-

Deep pink in May.

1 to 2 feet B. \& B.

A. VASEYI (Pinkshell)-Flow-

ers profusely before the leaves appear, exquisite pink or rose.

12 to 18 inches B. \& B.

A. VISCOSA (Swamp Azalea)

-Early fragrant white.

12 to 18 inches B. \& B

18 to 24 inches B. \& B

THE LIST ABOVE includes deciduous varieties. For Evergreen Azaleas see page 9. This species is representative of some of the finest color of bloom and delicacy of foliage. They do best in woods earth and partial shade with ample moisture. The deciduous native varieties have an ultimate height of about 6 feet. In carlots we can offer very special prices.
RED LEAF BARBERRY (B. Thunbergii atropurpurea)Leaves are purplish red all summer, a unique note in the foliage scheme. New.

12 to 15 inches.

WHITE FRINGE (Chionan-

thus Virginica)-Large shrub with white, fringe-like flowers, fragrant, in May. Rare.
2 to 3 feet.
$1.75 \quad 14.00$
3 to 4 feet
$2.00 \quad 18.00$

PHILADELPHUS VIRGINAL (Double Syringa)--Blooms nearly all summer, white, fragrant, double flowers. New.

2 to 3 feet.

3 to 4 feet

$.60 \quad 5.00$

MAYFLOWERED VIBURNUM

(V. Carlesii)-Medium shrub with very fragrant clear pink blooms in May. Rare.

18 to 24 inches.

2 to 3 feet.

$\begin{array}{lll}3.00 & 22.50 & 195.00\end{array}$

5.50

NEW FRENCH LILACS

MRS. EDWARD HARDING-

Double, bright carmine, big panicles, large flowers.

18 to 24 inches.

$4.00 \quad 35.00$

JAN VAN TOL-Single pure white. Large trusses, profuse bloomer.

18 to 24 inches.

$2.00 \quad 20.00$

KATHERINE HAVEMEYERDouble cobalt blue, enormous flower, perfect shape.

18 to 24 inches.

$4.00 \quad 35.00$

We also have a fine list of other New French Varieties, on which we will gladly quote prices.

STRIKING color effects throughout the summer can be arranged readily by consulting the table on the next page.

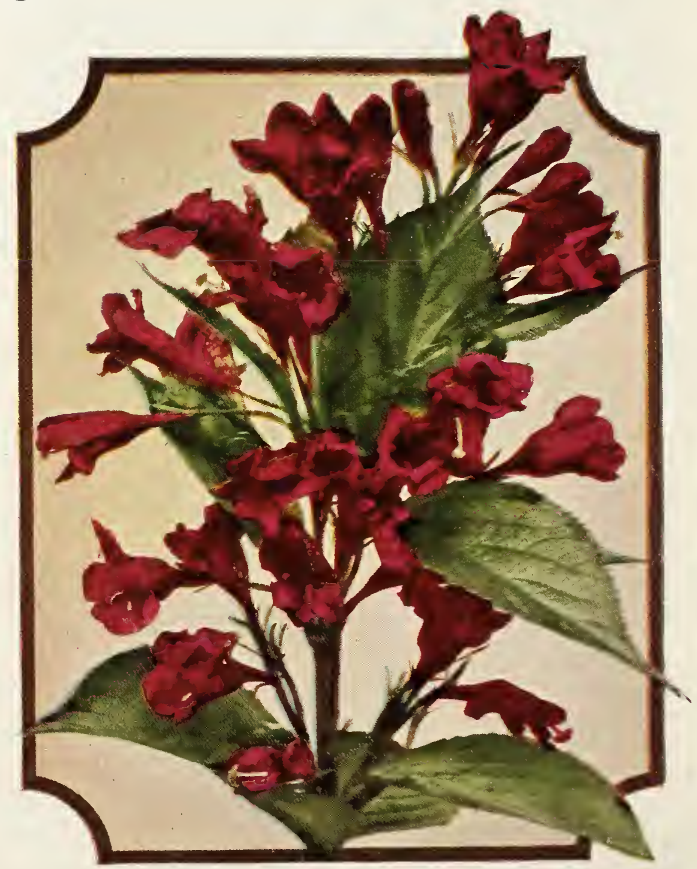

Weigelia Eva Rathke 
Name

$\begin{array}{ccc}\text { Color } & \text { Time } & \text { Ultimate } \\ \text { of Bloom } & \text { of Bloom } & \text { Height }\end{array}$

Notes

(Prices per 10)
18-24 in 2-3 ft. 3-4 ft.

ALTHEA (Rose of Sharon or

Hibiscus)
Hibiscus Syriacus ........ Red to White.. September

AMORPHA FRUITCOSA (Indigo)

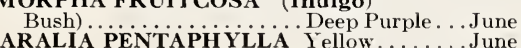

$8-10 \mathrm{ft} . \quad$ EIJ-Flowers in Fall.................... $\$ 5.00 \$ 8.00$

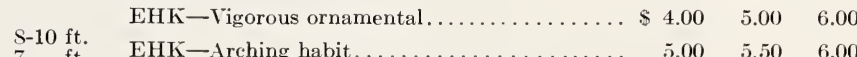

BUTTERFLY BUSH (Buddleia)

UTTERFLY BUSH (Buddleia)
Buddleia Magnifica..... Lilac ........... July to frost $5-6 \mathrm{ft}$.
CALYCANTHUS FLORIDUS (Sweet

Shrub) ............... Red-Brown...June to Sept. $4-5 \mathrm{ft}$.

DHJ-Attracts butterflies.

$2.50 \quad 4.00$

EHK-Fragrant blooms all summer.

.. $6.00 \quad 8.00$

DEUTZIA (Deutzia)

D. Crenata flora plena .... Rose......... . June

$6 \mathrm{ft} . \quad$ EHJ $\longrightarrow$ Shelter in winter.

D. Candidissima ......... White . June $\quad 6-8 \mathrm{ft} . \quad$ EHJK-Very vigorous..

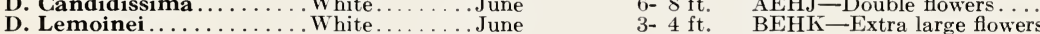

\begin{tabular}{rrr}
$\cdots$ & 5.00 & 6.00 \\
2.00 & 3.00 & 4.00 \\
5.00 & 3.00 & 4.00 \\
\hline & 7.00 & 10.00
\end{tabular}

DOGWOOD (Cornus)

C. Stolonifera (Red Dog-

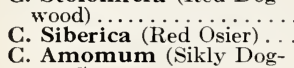

White........ June

C. Amomum (Sikly Dog-

.White....... June

$6 \mathrm{ft}$. FHK-Effective in winter.

8 ft. FHK-Good in wet places.

3.00

8 ft. FHK-Moist places...

\section{EUONYMUS}

E. Alatus (Winged Burning

Bush) ............. Yellow and Red June

$6 \mathrm{ft}$ EGK-Beautiful crimson foliage in fall,

$\begin{array}{lll}10.00 \quad 12.00 & 18.00\end{array}$

FORSYTHIA (Forsythia)

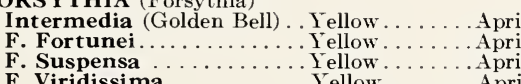

pril

F. Suspensa .......... Yellow

April

$\begin{array}{ll}\mathrm{S} & \mathrm{ft} . \\ \mathrm{S} & \mathrm{ft} . \\ 8 & \mathrm{ft} . \\ 8 & \mathrm{ft} .\end{array}$

AEHK-Branches gracefully arched

EHK -Bell shaped flowers...

AEHK - Branches gracefully arched.

HONE YSUCKLE (Lonicera)

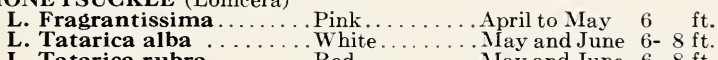

L. Tatarica rubra ....... Red.

L. Morrowi............. White

May and June 6- $8 \mathrm{ft}$.

May and June $6-8 \mathrm{ft}$.
May and June $6 \mathrm{ft}$

EHK - Branches more erect

May and June $7 \mathrm{ft}$.

EIJ-Almost evergreen

BEHK - Red fruit in autum

BEHK -Red variety

AEHK-Upright, dense growth .

LILAC (Syringa)

S. Vulgaris . . . . . . . . Purple ........ Iay

$8-10 \mathrm{ft}$.

EHK-Prune in early June

(White form of above)

6- $8 \mathrm{ft}$. EHK-All colors but yellow.

Lilac Hybrids (Named varie-

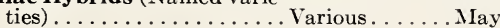

5.00

5.00

4.00

6.00

3.00

4.00

$\dot{5} . \dot{0} \dot{0}$

HYDRANGEA (Hydrangea)

H. Paniculata Grandiflora White
H. Aborescens Grandiflora White

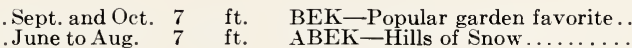
June to Aug. $7 \mathrm{ft}$.

QUINCE (Cydonia)

SNOWBERR Y (Symphoricarpos)

S. Vulgaris (Coral Berry) ...Pink ... . . . . July

July

4 ft. EHK-Currant-like fruit, red.

SPIRAEA (Spiraea)

S. Anthony Waterer. . . . Crimson...... July and Aug. 2- $3 \mathrm{ft}$.

S. Callosa Alba ..........White.......... June to Sept. ${ }_{2} \mathrm{ft}$

S. Douglassi...........................

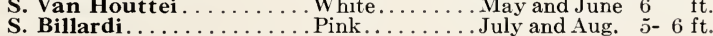

AEK-Cut faded blooms

AEK-Fine dwarf

EHK-Blooms in dense panicles

EHK-The favorite Spiraea.

EHK - Good for hills or dry places.

6.00

7.00

TEPHANANDRA (Lace Shrub)
S. Flexuosa ...........White.......July . ..... 3- $4 \mathrm{ft}$.

EHIJ-A fine low shrub with dense, deep green

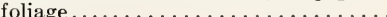

SYRINGA (Philadelphus)

P. Coronarius (Mock

P. Grandifiora

White.........May to June

P. Lemoine.

$\begin{array}{lll}\text { White......... May to June } & \mathrm{s} & \mathrm{ft} \\ 4 & \mathrm{ft}\end{array}$

EHK-Atractive foliage

BHK - Excellent dwarf shrub

TAMARIX (Tamarisk)

T. Africana........................... April and May $8-10 \mathrm{ft}$.

EHIJ-Fine feathery foliage

4.00

IBURNUM (Viburnum) . White ...... Jay and June 6- $8 \mathrm{ft}$

V. Opulus (Bush Cranberry) White.

May and June $6-8 \mathrm{ft}$.

V. Op. Sterlis (Common

Snowball)

May and June 6- $8 \mathrm{ft}$

EHK-Blue-black fruit

EHK-Fruit edible...

AEGK-Old garden favorite

$\begin{array}{ll}6.00 & 8.00\end{array}$

V. Tomentosum

White.

June

WEIGELIA (Diervilla)

Weigelia Rosea .

W. Candida.

$\begin{array}{lll}\text { Pink.......... June } & 6 & \mathrm{ft} \\ \text { White.......June and July } & 8 & \mathrm{ft}\end{array}$

ADHJ-Good foliage

ADH.J-Large showy flowers.

W. Eva Rathk

Wrimson......... June and July

ft. ADHJ-Very fragrant flowers . 


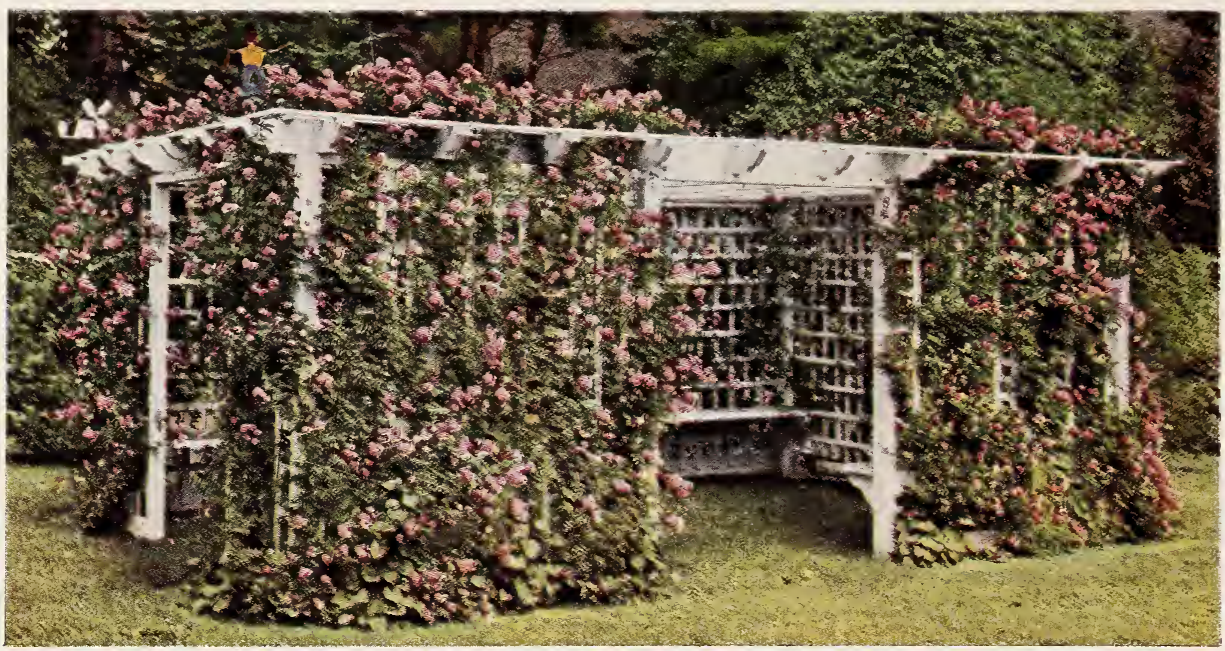

Effective use of climbing roses

\section{ROSES}

The F. W. Kelsey Nursery Company offers a complete list of both the rare and new and the standard varieties of Roses. Our selected list consisting of forty varieties of Hybrid Teas and twenty varieties of Hybrid Perpetuals is available on request. Besides, we can furnish at low prices many varieties which are often unobtainable elsewhere.

Send us list of the varieties you want particularly and we will make a special quotation.

All Roses are field grown.

\section{HYBRID TEA ROSES \\ 2 year, number 1 \\ HYBRID PERPETUAL ROSES \\ 2 year, number $1 \ldots$ \\ 2 year, number 1 . \\ The following either rare or special climbing varieties are also offered. Paul's Scarlet Climber (vivid scarlet semi-double; profuse and hardy). Silver Moon (silvery- white; does not mildew), Dr. Van Fleet (large double, flesh pink, fragrant), Mary Wallace New Van Fleet Climber. Semi-double rose-pink.}

$$
\text { (Each) }
$$

(100)

$\$ 1.20 \$ 9.00 \$ 75.00$

All 2-year Number 1

$\begin{array}{lll}1.00 & 7.00 \quad 60.00\end{array}$

\section{VINES AND GROUND COVERS EVERGREEN TYPES}

The following varieties of evergreen plants which may be used for ground cover have been selected as being most likely to give you satisfaction. All 2-year, number 1 plants.

ENGLISH IVY (Hedera helix).

EVERGREEN BITTERSWEET

(Euonymus radicans) - Very hardy, thrives in shade.

EUONYMUS VEGETUS - larger leaved, scarlet fruit in autumn ........ terminalis) - very hardy, low growing plant, will grow in shade where other plants die.

(Special prices in quantity)

MYRTLE (Vinca minor)-Trailing plant good in partial shade; blue flowers in May

(\$90.00 per thousand)
(10) (100)

$\$ 5.00 \$ 25.00$

\section{PLANT THESE UNDER RHODODENDRONS}

They will add to the beauty of the planting by covering bare spots and help keep the soil in the necessary acid condition

OCONEE BELLS (Shortia galicifolia) - Evergreen. White bell shaped flowers in early spring. Medium size transplants.

(10) (100) $\$ 2.50 \$ 16.00$

GALAX (Galax aphylla)-Beautiful heart shaped leaves turning scarlet when exposed to sun. Strong clumps.

$2.50 \quad 12.00$ (Special prices on both in quantity)

\section{HARDY PERENNIALS}

Only a few of the complete list of perennials from Achillea to Wallflowers can be listed here, but quotations will be gladly given on your list, be it long or short. We call especial attention, however, to

(Doz.)

$(100)$

CHR YSANTHEMUMS-Hardy, wide

range of colors, Singles, Doubles and

Buttons, bloom in October and November $\$ 2.00 \quad \$ 12.00$

SEDUM (Stonecrop)-dwarf edging succulents, perfectly hardy

\section{SPECIAL ROSE OFFER}

One Dozen selected Roses, two years field grown and number one grade for their age, for $\$ 6.00$, postage prepaid. This offer is made for one rose each of the following twelve varieties, all of them thoroughly tried and proved. We cannot substitute varieties in this offer at this special price.

Gruss an Teplitz

Etoile de France

J. L. Mock

Pink Radiance

Los Angeles

Columbia

Mme. Butterfly

Mrs. Aaron Ward

Sunburst

Souv. de Claud. Pernet

White Killarney

Frau Karl Druschki
Crimson

Crimson

Carmine-pink

Rose-pink

Salmon pink

Bright-Pink

Light Pink

Golden-buff

Orange-yellow

Yellow

White

White 


\section{WHEN TO PLANT}

Both Forestry Stock and other young Deciduous Trees and Evergreens are successfully planted both in Autumn and spring. Evergreens for spring planting April to June, and Deciduous Trees through March, April and May. The present season promises to be a favorable planting season.

\section{HOW TO PLANT}

The roots of smaller trees, seedlings or transplants, like larger trees. should never be permitted to dry out, and in planting it is desirable that

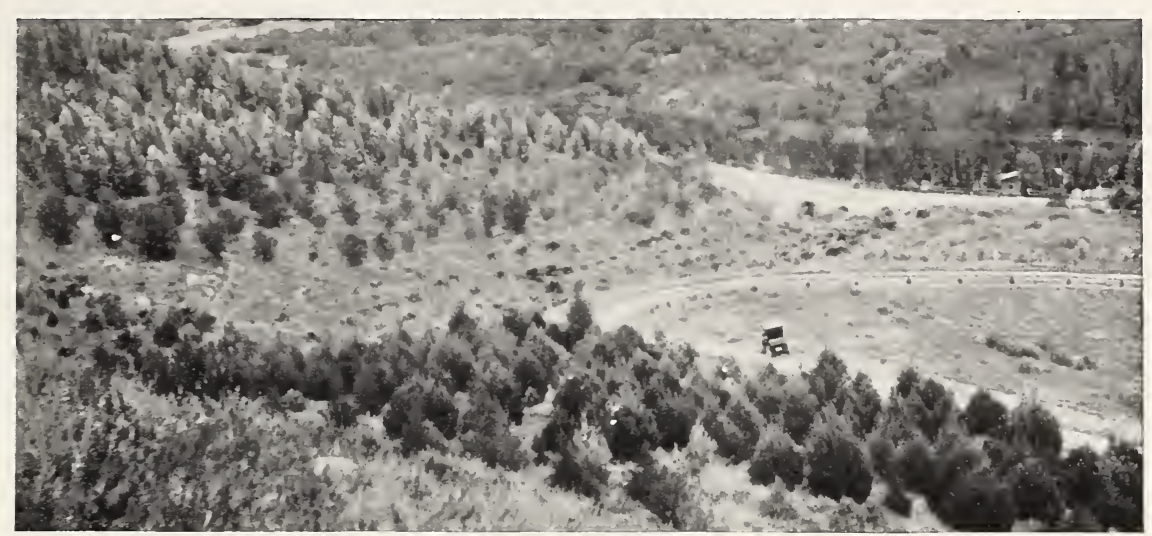

A barren hillside - six years after planting

each tree be set a little deeper than as grown in the nursery. It is also important to have the earth pressed firmly over the roots after they are placed in natural position. For forestry or timber growth, trees are generally planted anywhere from 4 to 6 feet apart each way; planted $4 x 4$ feet in the rows, 2,720 trees are required per acre; if $\tilde{j} \mathrm{x} \tilde{j}$ feet $1,7 \pm 0$; if $6 \times 6$ feet, 1,210 per acre. Transplants as a rule are more satisfactory for forestry or lining out purposes than seedlings. In this planting two men make an effective team at low cost: One man to open the hole, the other man to follow and plant; the trees being carried in a pail of muddy water until planted.

\section{PLANTING COSTS}

The economic side of the planting of young trees is, perhaps, not generally understood. A yearly income of 15 to 20 per cent on an investment in reforestation is well within the bounds of possibility if ordinary care and intelligence are exercised. This investment would, of course, be a longterm one of 20 to 50 vears.

The cost of planting is made up by reckoning the value of the land, the rearly taxes, the cost of labor in planting and the cost of the trees themselves. All these factors are variable, except that the actual labor of planting should average about $\$ 12.00$ per acre. The number of trees per acre in a $6 \times 6$ foot planting is 1,200, and in an average planting of Pine and Spruce these would cost for threeyear transplants \$25 to \$35 per acre. Seedlings would, of course, be much cheaper and more economical, but require

\section{DECIDUOUS VINES}

BOSTON IVY (Ampelopsis veitchi or tricuspidata)

2 year, number 1,2 to 3 feet

(10)

$\$ 6.00$

(100)

3 year, number 1 .

CLEMATIS PANICULATA-sweet scented star-shaped flowers, September. 2 year, number 1 .

HONEYSUCKLE (Lonicera halleana) 2 year, field grown.

WISTERIA - twining vine, large clusters purple flowers in May.

2 year, number 1.

\section{WHITE WISTERIA}

3 year, number 1

80.00

TRUMPET VINE (Bignonia radicans) -orange flowers in July; clings to rough surfaces, 2 year, number 1 . too much care on the average private estate where reforestation is purely a minor item and taken up as much for pleasure as for profit.

A typical cost budget per acre might be as follows:

\begin{tabular}{|c|c|}
\hline Cost of land . . . . . . . . . & $\$ 10.00$ (variable) \\
\hline Taxes at $.50 \mathrm{c}$ per year for 40 yrs. & 20.00 (variable) \\
\hline Cost of trees............ & 30.00 \\
\hline Planting......... & 12.00 \\
\hline Total. & $\$ 72.00$ \\
\hline
\end{tabular}

\section{PROFIT FROM TREES}

As against this cost the timber at the end of thirty years -in Spruces, Pines or Firs, should vield about 15,000 board feet at from $\$ 6$ per thousand for Pine up to $\$ 12$ per thousand for Spruce and Fir, or $\$ 90.00$ to $\$ 1 \$ 0.00$ total income per acre.

If cut for pulp-wood instead of lumber, the yield should be 30 to 45 cords per acre-at about $\$ 4.00$ per cord, or $\$ 120.00$ to $\$ 180.00$ per acre.

At 40 vears of age the board feet would range from 30 to 40 thousand feet per acre and the cords of pulp-wood also approximately double the figure for 30 vears. For this reason 40 rears is a much more economical period to crop the timberland.

The planting of White and Norway Spruce and Douglas and Balsam Fir for Christmas tree cutting is another phase of commercialized forestry which is profitable. This crop usually matures in about 12 years, and when cut, leaves the timber-lot properly spaced for forest growing. One tree is planted between each permanent tree and requires no extra land; indeed it is an assistance to the young evergreen for the first ten vears to have the shade and shelter of a dense planting, which must, however, be cleared away in time. whether for Christmas tree use or not, in order to maintain a six by six foot space for permanent growth.

\section{BEST EVERGREEN VARIETIES}

A few words about the commoner varieties might not be amiss. In the price list of Seedlings and Transplants in the back of this Guide will be found many varieties of Evergreens, Trees and Shrubs classified alphabetically according to botanical names, together with sizes and prices a vailable for sale.

NORWAY SPRUCE (Picea excelsa)-This variety is planted in preference to other spruces for two reasons: It will thrive when set out in dense shade and succeeds in heavy damp soil. Having a flat root system, it is suitable for shallow, rocky soils.

WHITE SPRUCE (Picea alba) is most suitable for paper pulp and succeeds wherever Norway Spruce succeeds. It is a trifle quicker in growth. 
DOUGLAS FIR (Pseudotsuga taxifolia) although more beautiful probably than the average forestry tree is very valuable for timber. Fairly quick growing, it is a highly desirable variety and thoroughly hardy.

EUROPEAN LARCH (Larix Europea) entirely different from our American species, this variety makes an excellent growth and the wood is very strong and durable. It requires a deep, fairly porous and moderately fresh soil. It is a rapid grower but needs sunlight. Best used in combination with other varieties.

SCOTCH PINE (Pinus Sylvestris) is the variety par excellence for poor soils-even dry sand wastes can be successfully covered with a thrifty stand of Scotch Pine. It is also the quickest growing pine in common use and this even on the most sterile soil.

WHITE PINE (Pinus strobus) is probably the most valuable timber tree, but must have a fairly good soil for best results.

RED PINE (Pinus resinosa) is perhaps the most popular pine for forestry planting in the east. It has practically no insect enemies and is successful on a wide range of soil-from coarse gravel to heavy clay.
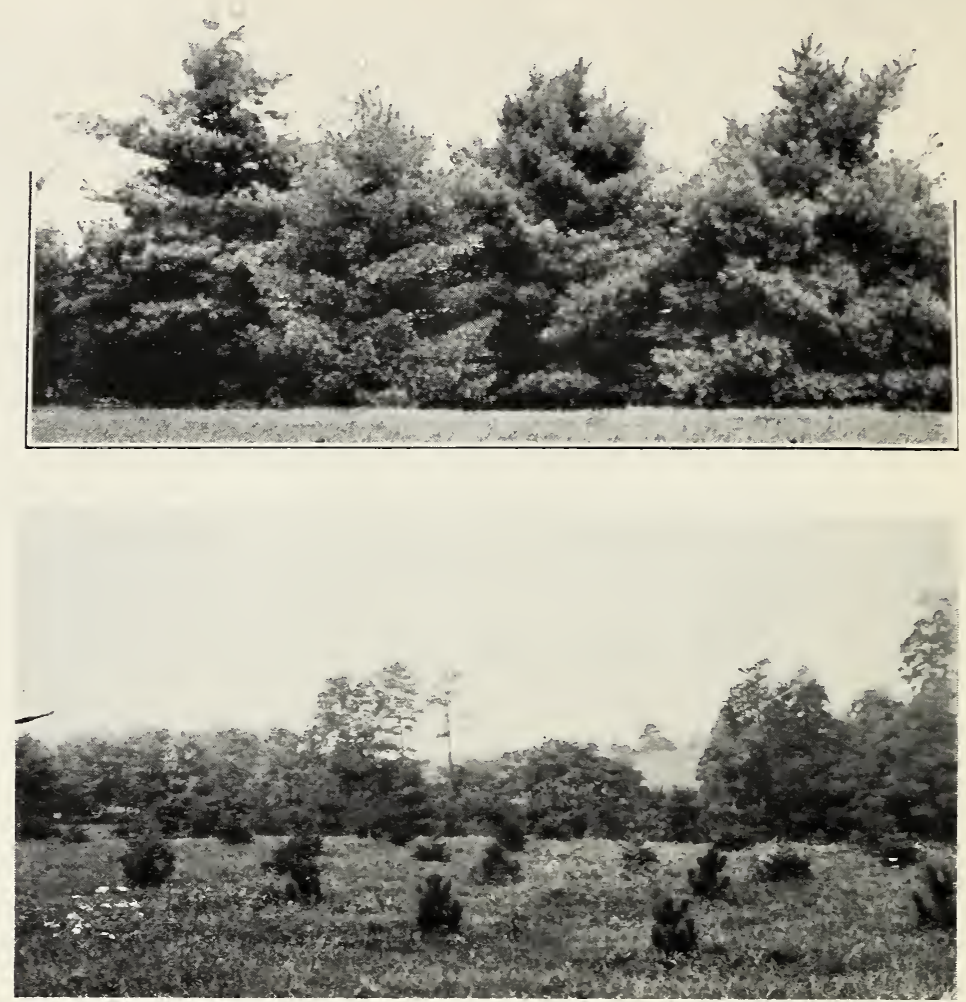

A remarkable picture. Above is taken in the same spot after 25 years of growth (White Pine)

CHRISTMAS TREE GROWING - This is particularly profitable in connection with a forest planting for pulp. Plant $3 \times 3$ feet-about 4,850 trees to the acre. At the end of approximately ten years take out every other tree for sale as Christmas trees, and leaving your planting $6 \times 6$ feet - the best distance for good timber growth. The best Christmas tree varieties are spruces and Firs.

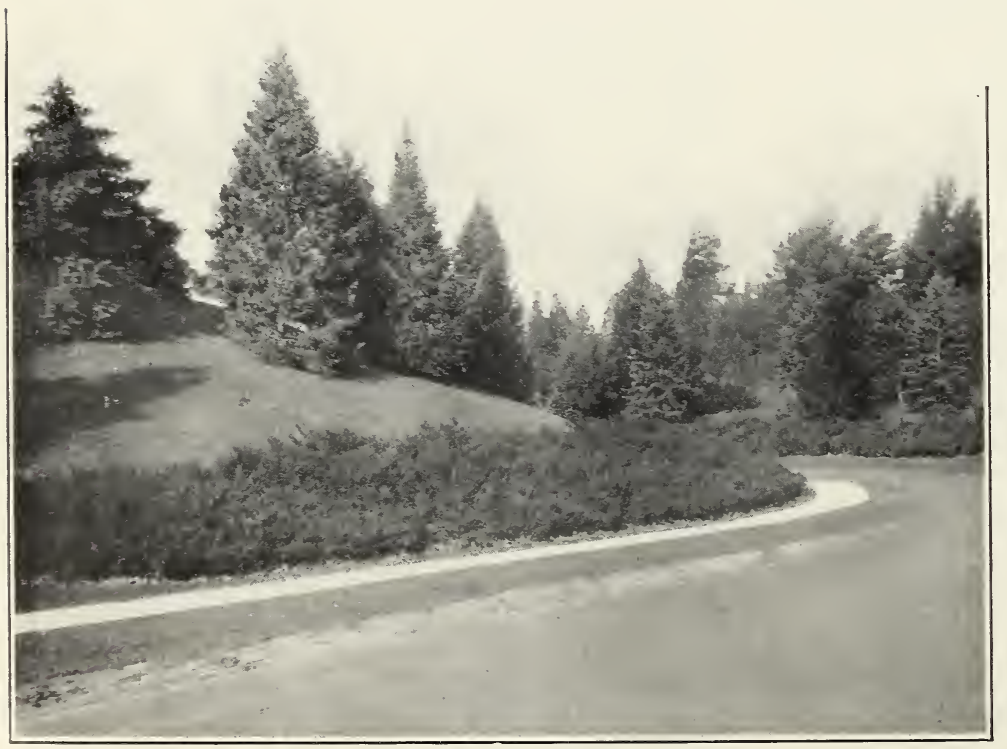

Woods planting need not lack beauty
CONSERVATION-All nature depends on the green leaf. Restore the forest and you restore nature. American Holly (Ilex Opaca) and Mountain Laurel (Kalmia) are fast disappearing from our woods. We offer small sizes for woods planting under Evergreen Shrubs in the green list opposite. Many shrubs whose berries provide winter food for birds are also noted therein.

\section{BEST VARIETIES FOR SPECI.AL SOILS}

\section{LIGHT SAND}

Scotch Pine (Pinus)

Black Locust (Robinia)

Carolina Poplar (Populus) SANDY LOAM

Red Pine (Pinus)

Black Locust (Robinia) Carolina Poplar (Populus)

European Larch (Larix)

Arbor Vitae (Thuya Occ.)

Douglas Fir (Pseudotsuga) GOOD SOIL

White Pine (Pinus)

Norway Spruce (Picea)

White Ash (Fraxinus)

European Larch (Larix) COARSE GRAVEL

Red Pine (Pinus)

Black Locust (Robinia) LOAM

White Pine (Pinus)

Norway spruce (Picea

White Ash Fraxinus

Carolina Poplar (Populus)

European Larch (Larix)

Arbor Vitae (Thura) WET LAND

Balsam Fir (Abies)

Arbore Vitae (Thuya Occidentalis)

Carolina Poplar (Populus) 


\section{FinAL BULLETIN OF FORESTRY AND LINING OUT STOCK}

\section{SPRING 1928}

Everything listed here is available in good supply -in some cases we can furnish more than a million of one size. Nevertheless, in a few weeks some of our customers will be disappointed in obtaining certain varieties they may order. We ask that orders be placed as early as possible. Many items are not listed here. Write us and we will quote them.
PRICES:-Net, packing at cost. Orders for 250 at thousand rate and 50 at hundred rate. Prices subject to change without notice. No order for small seedlings less than 100 .

TERMS:-Any claims for errors or shortages to be rendered within ten days after receipt of stock. Half cash in ad. vance, or acceptable references.

\section{Evergreen Tree Seedlings and Transplants}

" "X" Indicates each Transplanting ABIES (Fir)

balsamea (Balsam Fir)

Its characteristic clean odor and stately ap. pearance make this a desirable variety even without its well known value as timber. Ideal evergreen for wet land. Popular variety for Christmas trees.
3 yr. S., 3 to 7 inches.
$\$ 2.00$
4.00
$\$ 15.00$
brachyphilla (Nikko Fir)
concolor (White Fir)
2 yr. S.
$8.00 \quad 60.00$
30.00
120.00
...........

douglasi (Douglas Fir)

One of the most beautiful conifers, it is also

easy to grow and valuable as lumber. Popu

lar variety for Christmas trees.
2 yr. S...

3 to 6 in. $X$

6 to 10 in. $\mathrm{X}$.

8 to 10 in. X (Blue Strain)

12 to $15 \mathrm{XX}$ (Blue Strain)

firma (Momi Fir)

${ }_{\text {fraseri }}^{2}$ (Fraser Fir)

2 to 3 in. X........

pectinata (Silver Fir)

veitchi ${ }^{3}$ (Veitch's Fir)

3 yr. S

100)

$(1000)$

CEDRUS (True Cedar)

deodora (Deodar)
2 to 4 in. S....

CRYPTOMERIA (Japanese Cedar)

japonica

4 to 8 inch S.

20.00

$8.00 \quad 60.00$

$15.00 \quad 125.00$

$24.00 \quad 195.00$

$30.00 \quad 225.00$

290.00

30.00

50.00

50.00

45.00

80.00

CUPRESSUS (True Cypress)

lawsoniana (Lawson's Cypress)

Thoroughly hardy and a beautiful tree. Sim ilar in foliage to the Retinospora and Arborvitae.

$$
1 \text { yr. S. }
$$

Horticultural varieties of Lawson's

Cypress:- Triomphe de Boskoop,

Alumi and Fraseri

6 to 10 inch grafts........\$8. per $10 \quad \ldots \quad 70.00$

sempervirens (Italian Cypress)

1 yr. S

\section{JUNIPERUS (Junipers)}

cannarti (Cannart Red Cedar)

Rooted cuttings, 5 to 7 in.
communis (Common Juniper)

communis (Common Juniper)
6 to 8 in. 2 yr. S......-............

16.00

20.00

250.00

50.00 communis hibernica (Irish Juniper)

horizontalis (Prostrate Juniper)

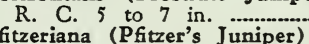

pfitzeriana (Pfitzer'

Rooted cuttings

sabina (Savin Juniper)

Rooted cuttings, 4 to

virginiana (Red 4 to 4 in. $S$

Grafted varieties of Juniperus:-Virginiana Grafted varieties of Juniperus:-Virginiana
glauca, V. Keteleri, V. Schotti, Squamata, Meyerii, V. Kosteri Fortunei.

6 to 10 in. grafts ....\$12. per $10 \ldots . . . . .$.

(100) $\quad(1000)$

$\begin{array}{ll}7.00 & 60.00\end{array}$

$21.00 \quad 195.00$

$18.00 \quad 160.00$

$28.00 \quad 250.00$

$11.00 \quad 95.00$

5.00

30.00

LARIX (Larch)

europea (European Larch)

A tall, straight grower, very different trom the native Larch, (or Hackmatack). It re. quires a deep, fairly porous and moderately fresh soil. It is a rapid grower but needs sunlight. Best used in combination with other varieties.

LARIX (Larch) Continued

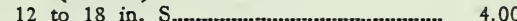

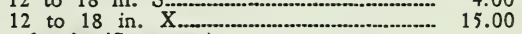

leptolepsis (Japanese)

2 yr. $\mathrm{S}$

2.00

30.00

95.00

PICEA (Spruce)

alba (White Spruce)

Most suitable for paper pulp and succeeds wherever Norway Spruce succeeds. It is a trifle quicker in growth. Popular variety for Christmas trees.

2 yr. S.

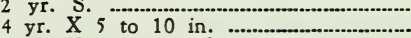

3 yr. X 2 to 4 inches

6 to 12 in. $\mathrm{XX}$

canadensis (Black Hills Spruce)

$1 \mathrm{yr} . . . \mathrm{s}$

3 to 6 in. $\mathrm{X}$

(Englemann's Blue)

3 yr. $\mathrm{Yr} 2$ to 3 in.

(Norway Spruce)

This variety is planted in preference to other spruces for two reasons: It will thrive when set out in dense shade and succeeds in heavy damp soil. Having a flat root system, it is suitable for shallow, rocky soils. Popular variety for Christmas trees.

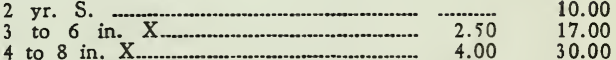

8 to 12 in. $\mathrm{XX}$

Koster's Blue

1 yr. grafts from field....................... 200.00

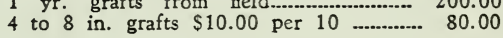


polita (Tigertail Spruce)

(100) (1000)

4 to 6 in. $X$

pungens (Colorado Blue Spruce)

This variety varies in color from light blue to light green. Unless stated "Selected Blue" our stock runs from 30 to $50 \%$ blue. In small sizes, it is usually cheaper to buy blue Spruce does not make all blue seedlings. inot make all blue seedlings. 2 yr. 4 to 6 in., 2 gr. S. Selected Blue...--..-

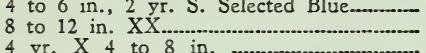
4 yr. $\mathrm{X} 4$ to 8 in. .............................. 8.00

20.00

75.00

285.00
60.00

Oriental Spruce

2 yr. S..................

2 yr. S...-...-...-...-...-..-

6.00

40.00

25.00

PINUS (Pine)

austriaca (Austrian Pine)

A fast grower, hardy, shapely, and bushy. Makes a fine specimen or a valuable timher growth. Uniquely adapted for sea shore screens.

2 yr. S

3 to 6 in $x$

6 to 9 in. $X$

6 to $1+$ in. $X \quad 5$ year.............................................. 12.00

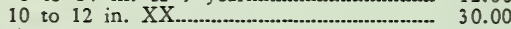

banksiana (Jack Pine)

3 yr. S.......

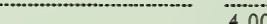

10 to 18 in $X$

densifloza (Jap. Red Pine)

Lighter foliage and more spreading than the Austrian Pine, but also thrives in sea shore

planting. Understock for grafting Jap. Table

Pine.

2 yr. S...

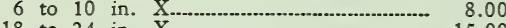

excelsa (Himalaya Pine)

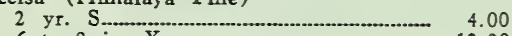

6 to 8 in. $X$

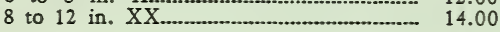

10.00

20.00

50.00

80.00

225.00

8.00

80.00

16.00

0.00

30.00

95.00

120.00

\begin{tabular}{|c|c|c|c|}
\hline mughus $\begin{array}{r}2 \\
2 \\
8 \\
8\end{array}$ & $\begin{array}{l}\text { (Mugho Pine) } \\
\text { yr. S. } \\
\text { to } 4 \text { in. } 3 \text { yr. X. } \\
4 \text { to } 6 \text { in. } X X . \\
\text { to } 10 \text { in. XXX }\end{array}$ & $\begin{array}{r}4.00 \\
5.00 \\
12.00 \\
50.00\end{array}$ & $\begin{array}{r}\$ 22.00 \\
32.50 \\
95.00 \\
400.00\end{array}$ \\
\hline
\end{tabular}

poiretiana (Corsican Pine)

2 yr. S. 4 to 6 in. ............................. $4.00 \quad 25.00$

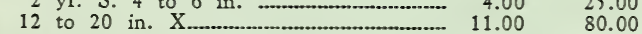

ponderosa (Western Yellow Pine)

4 to 8 in. Xine)

2 yr. S.....................

8.00

40.00

4.00

20.00

resinosa (Red Pine)

Perhaps the most popular pine for forestry

planting in the east. It has practically no

plansect enemies and is successful on a wide

insect enemies and is successful on a wide
range of soil-from coarse gravel to heavy range
clay.

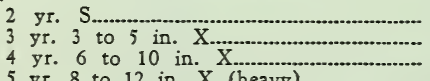

$\begin{array}{rr}2.00 & 12.00 \\ 4.00 & 25.00\end{array}$

$6.00 \quad 40.00$

5 yr. 8 to 12 in. $X$ (heavy).............. $10.00 \quad 70.00$

WHITE PINE (Pinus Strobus)

New England only

$\begin{array}{rrr}2 & \text { yr. } S \text { to } 7 \text { in. } X \\ 10 & \text { to } 18 \text { in. } X & 4.00 \\ 18 \text { to } 24 \text { in. } X & 8.00 \\ 18 & & \end{array}$

strobus (Ship almost anywhere)

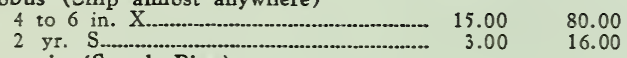

sylvestris (Scotch Pine)

The variety par excellence for poor soils-

even dry sand wastes can be successfully

covered with a thrifty stand of Scotch Pine.

It is also the quickest growing pine in common

use and this even on the most sterile soil.

3
12 to 18 in. $X$

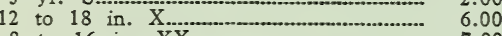

8 to 16 in. XX_............................ 7.00

tanyosho (Japanese Table Pine)

4 to 6 in. grafts $\$ 9.00$ per 10

80.00

6.00

25.00

45.00

600.00
RETINOSPORA (Japanese Cypress)

filifera

Rooted cuttings

pisifera

Rooted cuttings …................................... $11.00 \quad 95.00$

7 to 9 cuttings

pisifera aurea

Rooted cuttings

plumosa

Rooted cuttings

plumosa aurea

R. C.

squarrosa Rooted cuttings

obtusa

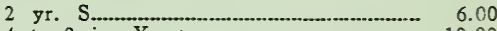

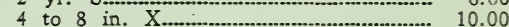

obtusa aurea Youngi $\quad \$ 8.00$ per $10 \ldots \ldots . . . . \quad 70.00$

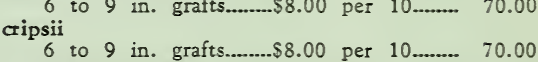

6 to 9 in. grafts......... $\$ 8.00$ per $10 \ldots . . . . . . .70 .00$

6 to 9 in. grafts........ $\$ 3.00$ per $10 \ldots . . . . . .60 .00$

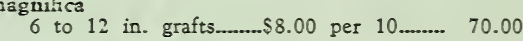

SCIADOPITYS (Umbrella Pine)

verticillata

2 yr. S

12.00

TAXUS (Yew)

Canadensis (Canadian Yew)

Rooted cuttings …....................................... 10.00

7 to 9 in. X

cuspidata (Japanese Yew)

8 to 10 in. X. 28.00

cuspidata brevifolia (Dwarf Jap. Yew)

8 to 10 in. X............

cuspidata capitata (Upright)

repandens (Dwarf English)

baccata (English Yew)

Rooted cuttings ........

THUJA (Arborvitae)

occidentalis (White Cedar)

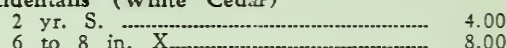

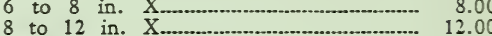

pyramidalis

Rooted cuttings

Siberian

Rooted cuttings ................................................ 9.00

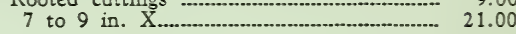

erecta

Rooted cuttings ………………............... 9.00

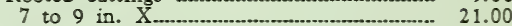

hoveyi

Rooted cuttings ……............................. 10.00

7

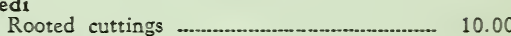

Tom Thumb

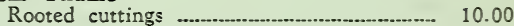

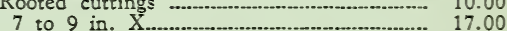

globosa

Rooted cuttings .............................................. 11.00

alba spicata

osedele cuttings

Rooted cuttings

erricoides

Rooted cutting
7 to 9 in. X.

orientalis (Biota)

2 yr. $S$ to 12 in. $X$

6 to 12
Standishii

8 to 12 in. grafts........ $\$ 6.00$ per $10 \ldots \ldots . . .50 .00$

Lobby atrovirens

8 to 12 in. grafts........ $\$ 6.00$ per $10 \ldots . . . . . .50 .00$

Douglasi aurea

6 to 10 in. grafts........ $\$ 6.00$ per $10 \ldots \ldots . . . \quad 50.00$

Thuyopsis (Blue Nootka Cypress)

borealis glauca

6 to 10 in. grafts.

TSUGA (Hemlock)

canadensis (Amer. Herrlock)

2 to 4 in. $\mathrm{S}$

5 to 8 in. $\mathrm{X}$
95.00

(1000)

140.00

270.00

140.00

90.00

120.00

100.00

50.00

80.00

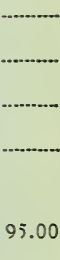

90.00

200.00

240.00

260.00

240.00

240.00

200.00

20.00

70.00
90.00

70.00

80.00

185.00

80.00

185.00

90.00

200.00

90.00

90.00

160.00

95.00

95.00

95.00

95.00

160.00

20.00

90.00

400.00

400.00

400.00 


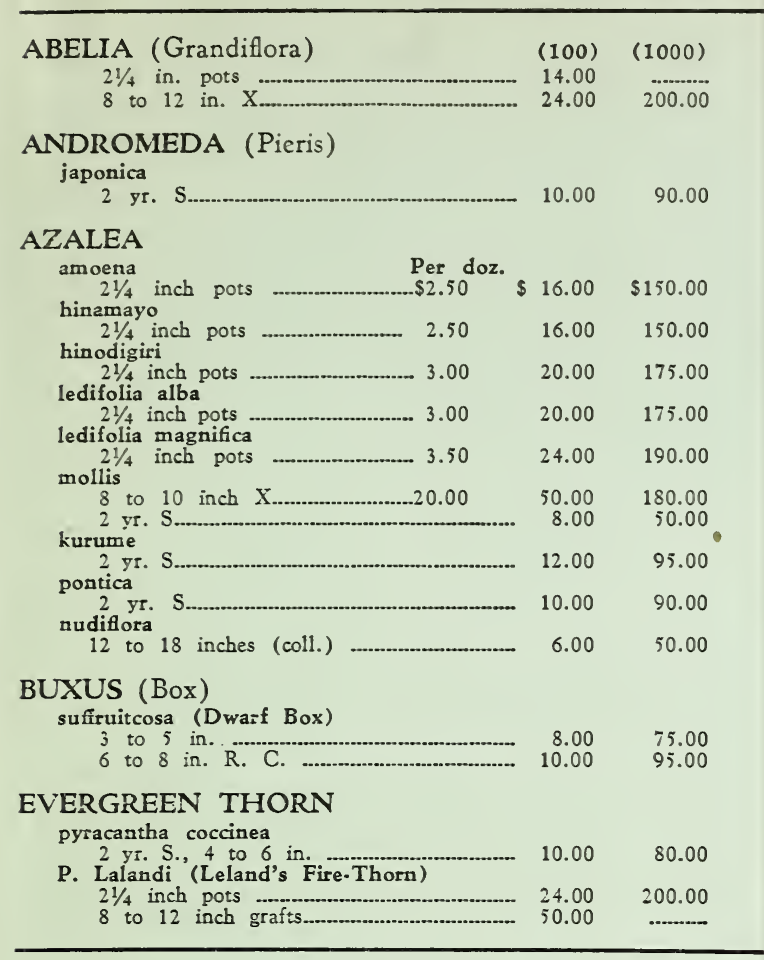

\section{E C I D U O}

(Prices are quoted per 1000, but we will furnish 250 at the sar

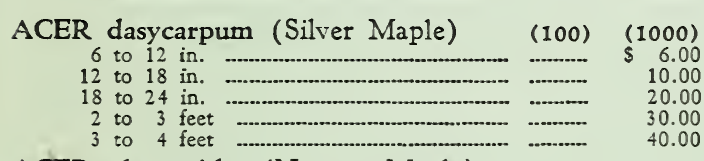

ACER platanoides (Norway Maple)

Perhaps the best all-round shade tree for streets. The Prices quoted on the three larger sizes include cost of packing and transportation anywhere in U. S. A.

$\begin{aligned} 6 & \text { to } 12 \text { in. S } \\ 12 & \text { to } 15 \text { in. }\end{aligned}$

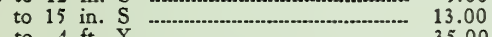

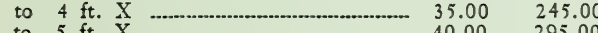

295.00

ACER rubrum (Red Maple)

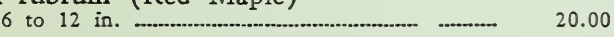

ACER saccharum (Sugar Maple)

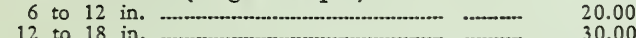

$$
\begin{aligned}
& 12 \text { to } 18 \text { in. } \begin{array}{rrr}
30.00 \\
4
\end{array}
\end{aligned}
$$

ACER

palmatum atropurpureum (Jap. Blood-leaf Maple)

ACER 6 to 10 inch grafts $\$ 12$. per $10, \ldots$-......... $\$ 95.00$ per 100

palmatum atro. dissectum (weeping)

(Jap cut leaved purple Maple)

ACER

6 to 10 inch grafts $\$ 12$. per 10

$\$ 95.00$ per 100

palmatum aureum. (Sunrise Maple)

AILANTHUS (Tree of Heaven)

$\$ 120.00$ per 100

glandulosa

12 to 18 in.

14.00

AESCULUS (Flowering Horse-Chestnut)

hippocastanum 6 to 12 in

BETULA alba (White Birch)

$\begin{array}{rr}6 & \text { to } 9 \text { in. } \\ 12 & \text { to } 18 \text { in. }\end{array}$

18 to 24 in. 18 in. 120.00

BETULA populifolia (Gray Birch)

12 to 18 in.
AMPELOPSIS (Ivy)

A. veitchi (Boston Ivy)

(100) (1000)

1 yr. 12 to 18 in.

4.00

6.00

a yr. X.olia (Virginia Creper)

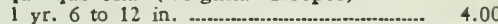

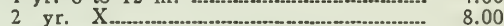

\section{ARISTOLOCHIA}

Sipho (Dutchmans-pipe)

$$
2 \text { yr. S }
$$

AZALEA (See Evergreen Shrubs)

\section{BERBERIS (Barberry}

Very attractive to birds, including Grouse, Quail, Lark, Loon and Snipe. Provides food all winter.

thunbergi (Japanese)

3 to 6 in. S.

12 to 15 in. S.

18 to 24 in. X (heavy)

CRATAEGUS (Hawthorn)

coccinea

12 to 18 in. $\mathrm{S}$

oxycantha

9 to 12 in $X$

CYDONIA (Quince)

japonica (Japanese)

8 to 12 in. $S$

\section{DEUTZIA}

D. Lemoine, Rosea, Pride of Rochester

10 to 18 in. 8.00

D. GRACILIS

6 to 12 in.

FORSYTHIA

fortunei

12 to 18 in 5

suspensa

12 to 18 in. S.

25.00

50.00

30.00

70.00

40.00

HYDRANGEA

paniculata grandiflora 6 to 12 in.

ROSA (Rose)

A planting of roses gives winter food to Grouse, Prairies Chicken, Bobwhite and Robins.

multiflora

1 प्र. No. 1

blanda 12 in. $\mathrm{S}$

12 to

12 to 18 in. $\mathrm{S}$.

10.00

12.00

setigera

Climbing Roses: Dorothy Perkins,

White Perkins, Crimson Rambler,

Dr. Van Fleet, Gold Finch, Clb.

Amer. Beauty, Tausendschoen, Sil-

ver Moon, Pauls Scarlet.

$$
21 / 2 \text {-in. pots }
$$

(

10.00

6.00

INGA (Lilac)

persica (Persian Lilac)

12 to 18 in

rothmagensis

12 to 18 in.

villosa

4 to 6 in. S...... Purple)
vulgaris (Common Pula

2 yr. S 4 to 8 in

75.00

50.00

30.00

\section{VIBURNUM}

More than half the native birds relish the berries, including Grouse, Partridge, Woodcock, Snipe and Phaesant.

V. Lantana

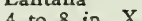

V. Americana

V. 8 to 12 in

V. opulis sterilis

WEIGELA (Diervilla)

rosea

12 to 15 in.

Only a few of the more popular varieties of shrubs are listed here. Write for quotations on any other items you may want. 
polita (Tigertail Spruce)

$(100) \quad(1000)$

pungens (Colorado Blue Spruce)

This variety varies in color from light blue to light green. Unless stated "Selected Blue " our stock runs from 30 to $50 \%$ blue. In small sizes, it is usually cheaper to buy unselected trees. Even seed from the Koster blue Spruce does not make all blue seedlings.

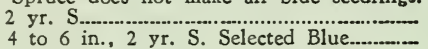

4 to 6 in., 2 yr. S. Selected Blue..........-

4 to $\mathrm{X}, 4$ to 8 in.

Oriental Spruce

2 yr. S......

sitkaensis (Sitka Spruce)

2 yr. S.........-...-

PINUS (Pine)

austriaca (Austrian Pine)

A fast grower, hardy, shapely and bushy.

Makes a fine specimen or a valuable timher growth. Uniquely adapted for sea shore screens.

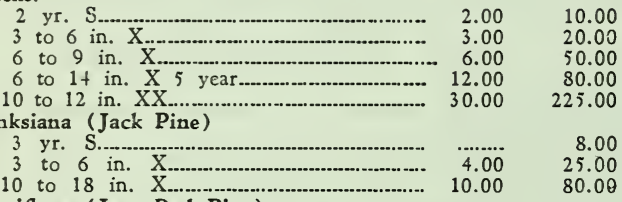

densifloza (Jap. Red Pine)

Lighter foliage and more spreading than the Austrian Pine, but also thrives in sea shore planting. Understock for grafting Jap. Table

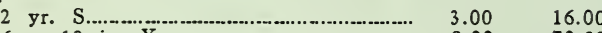

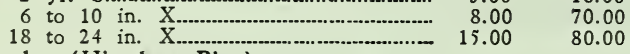

excelsa (Himalaya Pine)

2 yr. S.

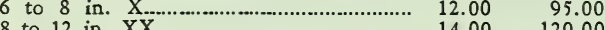

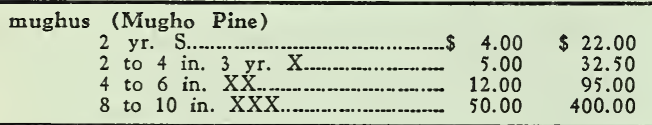

poiretiana (Corsican Pine)

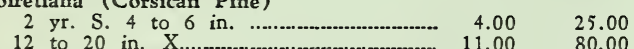

ponderosa (Western Yellow Pine)

4 to 8 in. X............ 8.00

$8.00 \quad 40.00$

rigida (Pitch Pine)

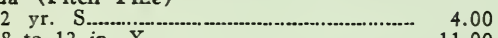

8 to 12 in. X

resinosa (Red Pine)

Perhaps the most popular pine for forestry

planting in the east. It has practically no

insect enemies and is successful on a wide

range of soil-from coarse gravel to heavy clay

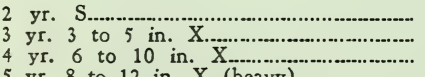

$2.00 \quad 12.00$

$4.00 \quad 25.00$

$6.00 \quad 40.00$

5 yr. 8 to 12 in. $X$ (heavy).................. $10.00 \quad 70.00$

WHITE PINE (Pinus Strobus)

New England only

\begin{tabular}{|c|c|}
\hline $\begin{array}{l}2 \text { yr. } \\
3 \text { to } 7 \text { in. } \mathrm{X} \\
0 \text { to } 18 \text { in. } \mathrm{X} \\
8 \text { to } 24 \text { in. } \mathrm{X}\end{array}$ & (n) \\
\hline
\end{tabular}

strobus (Ship almost anywhere)

4 to 6 in. X.......................................... $15.00 \quad 80.00$

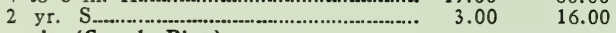

sylvestris (Scotch Pine)

The variety par excellence for poor soils-

even dry sand wastes can be successfully

even dry sand wastes can be successfully
covered with a thrifty stand of Scotch Pine.

covered with a thrifty stand of Scotch Pine.
It is also the quickest growing pine in common

use and this even on the most sterile soil.

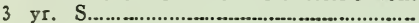

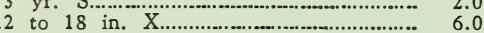

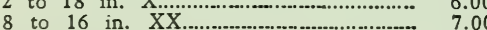

tanyosho (Japanese Table Pine)

4 to 6 in. grafts $\$ 9.00$ per 10

80.00

6.00
25.00

45.00

600.00
RETINOSPORA (Japanese Cypress)

(100)

filifera

Rooted cuttings

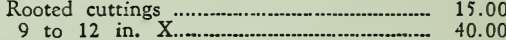

pisifera

Rooted cuttings

isifera aurea

Rooted cuttings

plumosa

Rooted cuttings

plumosa aurea

R. C. .

squarrosa
Rooted cuttings

obtusa

$$
2 \text { yr. S. } 4 \text { to } 8 \text { in. } \mathrm{X}
$$

obtusa aurea Youngi

6 to 9 in. grafts........\$8.00 per 10 ........ 70.00 cripsii

6 to 9 in. grafts........\$8.00 per $10 \ldots \ldots . . .70 .00$ gracilis

6 to 9 in. grafts........ $\$ 8.00$ per $10 \ldots . . . . . .60 .00$

magnifice
6 to 12
in. grafts......... $\$ 8.00$ per $10 \ldots . . . . .$.

70.00

SCIADOPITYS (Umbrella Pine)

verticillata

2 yr. S.

12.00

TAXUS (Yew)

Canadensis (Canadian Yew)

10.00

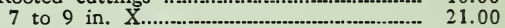

cuspidata (Japanese Yew)

cuspidata brevifolia (Dwarf Jap. Yew)

8 to 10 in. $X$....................

8 to 10 in. $X$...............

repandens (Dwarf English)

6 to 8 in. X......

Rooted cuttings

28.00

29.00

29.00

29.00

24.00

95.00

90.00

200.00

240.00

260.00

240.00

240.00

200.00

THUJA (Arborvitae)

occidentalis (White Cedar)

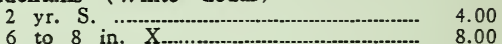

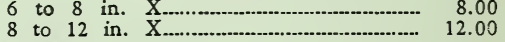

pyramidalis

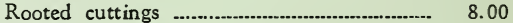

Siberian

Rooted cuttings

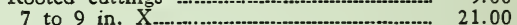

erecta

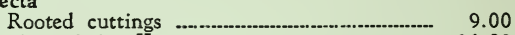

7 to 9 in. $X$

hoveyi

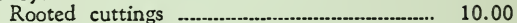

7 to 9 in. $X$

reedi

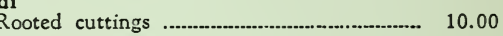

Tom Thumb

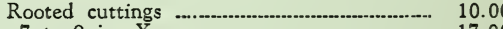

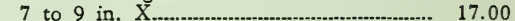

globosa

Rooted cuttings

alba spicata

Rooted cuttings

Rosedale Hybrid

Rooted cuttings

erricoides

Rooted cuttings

orientalis (Biota)

2 yr. S...........

6 to 12 in. $X$

Standishii

8 to 12 in. grafts......... $\$ 6.00$ per $10 \ldots . . . . . .50 .00$

Lobby atrovirens

8 to 12 in. grafts........ $\$ 6.00$ per 10 ........ 50.00

Douglasi aurea

6 to 10 in. grafts........\$6.00 per $10 \ldots . . . . \quad 50.00$

Thuyopsis (Blue Nootka Cypress)

borealis glauca

6 to 10 in. grafts.

70.00

TSUGA (Hemlock)

canadensis (Amer. Hemlock)

2 to 4 in. S............................. 2.50

5 to 4 in. 8 in. X

15.00

PSEUDOTSUGA (See Abies) 


\section{E V E R G R E N S H U B S}

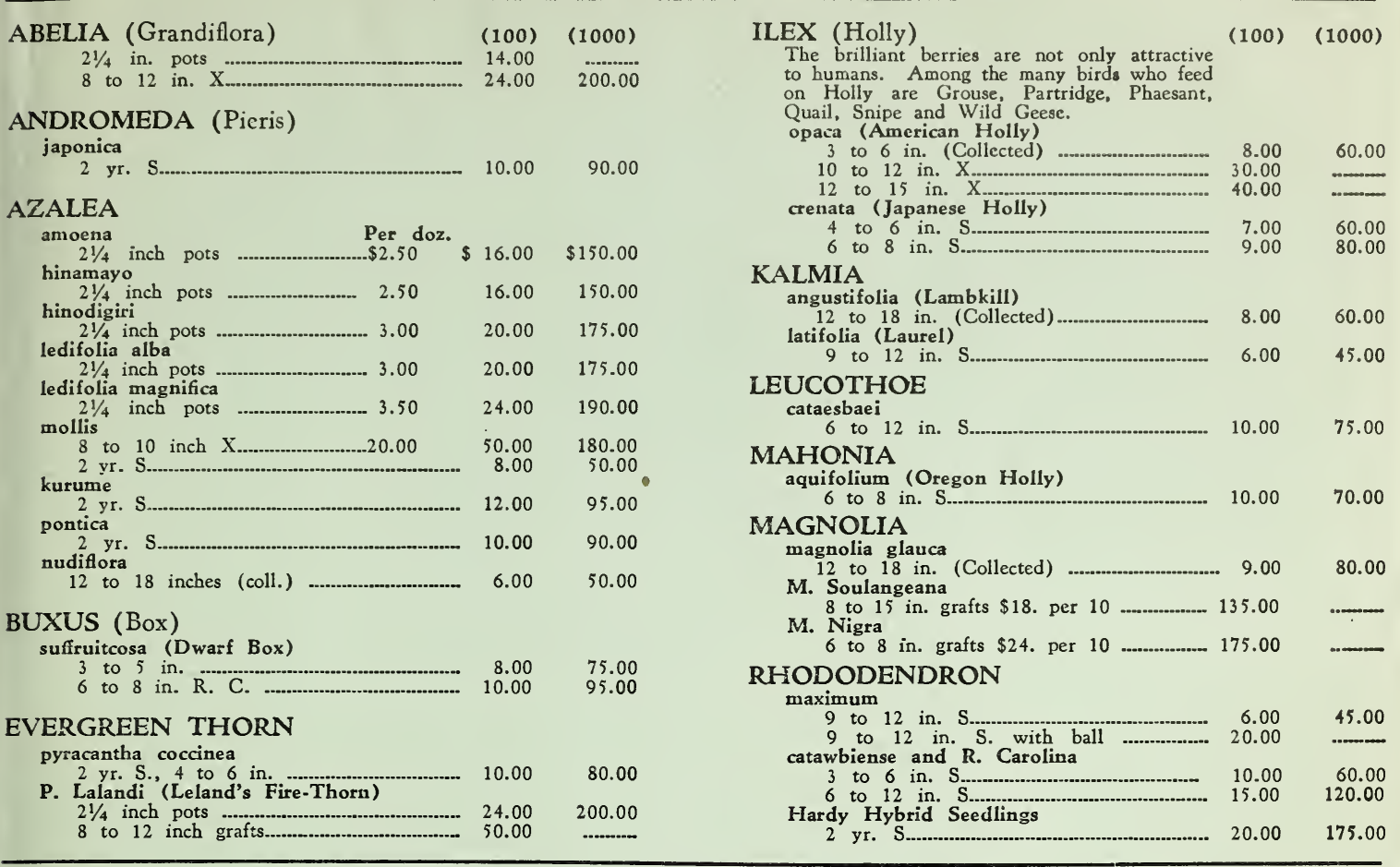

\section{E C I D U O U S T R E E S}

(Prices are quoted per 1000, but we will furnish 250 at the same rate. For smaller quantities than 250, add $50 \%$ to these prices. No order less than 50 .)

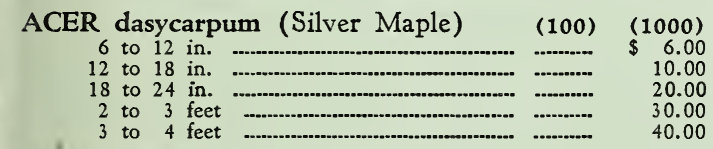

ACER platanoides (Norway Maple)

Perhaps the best all-round shade tree for streets. The Prices quoted on the three larger sizes include cost of packing and transportation anywhere in U. S. A.

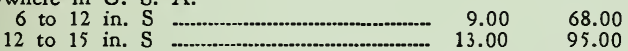

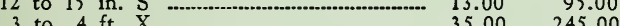

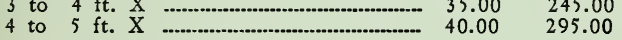

ACER rubrum (Red Maple)

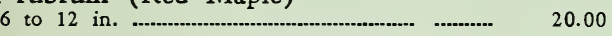

ACER saccharum (Sugar Maple)

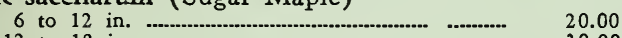

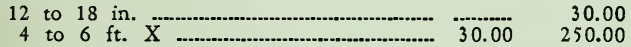

ACER

palmatum atropurpureum (Jap. Blood-leaf Maple)

ACER 6 to 10 inch grafts $\$ 12$. per $10, \ldots-\ldots-\ldots$

palmatum atro. dissectum (weeping)

(Jap cut leaved purple Maple)

ACER

6 to 10 inch grafts $\$ 12$. per $10, \ldots . . . . . . . . . .-\$ 95.00$ per 100

palmatum aureum. (Sunrise Maple)

grafts -. TUS (Tree of Heaven)

$\$ 120.00$ per 100

AILANTHUS (Tree of Heaven)

glandulosa

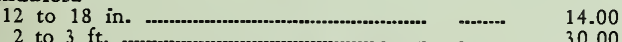

AESCULUS (Flowering Horse-Chestnut)

hippocastanum

6 to 12 in.

BETULA alba (White Birch)

6 to 9 in.

12 to 18 in.

30.00

30.00

\begin{tabular}{rr}
$0 .+\cdots$ & 80.00 \\
\hline
\end{tabular}

120.00

BETULA populifolia (Gray Birch)

12 to 18 in.
BETULA papyrifera (Paper Birch) (100) (1000)

12 to 18 in. 20.00

BETULA lutea (Yellow Birch)

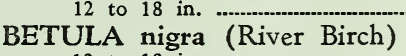

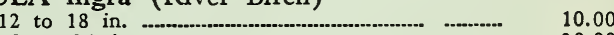

18 to 24 in. 20.00

CATALPA speciosa (Western Catalpa)

12 to 18 in.

18 to 24 in.

CARPINUS americana (Hornbeam)

12 to 18 in. ...-...-...-..-

CERCIS canadensis (Red Bud)

6 to 12 in.

12 to 18 in.

18 to 24 in.

3 to 4 ft. X

CORNUS FLORIDA (Flowering Dogwood)

6 to 12 in.

8.00

10.00

20.00

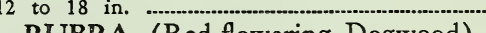

C. FL. RUBRA (Red-flowering Dogwood)

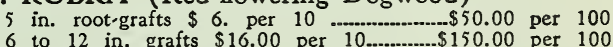

FAGUS ferruginea (American Beech)

6 to 12 in. ........................ (Purple

FAGUS purpurea (Purple Beech)

30.00

8 to 10 in. grafts $\$ 12.00$ per 10 . ................ $\$ 95.00$ per 100

FAGUS riversii (River's Purple Beech)

10 to 15 in. grafts $\$ 12.00$ per $10 \ldots \ldots+\ldots 80.00$ per 100

FAGUS pendula (Weeping Beech)

12 to 18 in. grafts $\$ 12.00$ per 10 .................. $\$ 90.00$ per 100

FAGUS heterophylla (Fernleaf Beech)

8 to 12 in. grafts $\$ 12.00$ per 10 .............. $\$ 90.00$ per 100

FRAXINUS (American White Ash)

6 to 12 in.

GINGKO BILOBA (Maidenhair)

6 to 8 in. (Honey Locust)

6 to 12 in.

80.00

12 to 18 in.

10.00

14.00 


\section{DECIDUOUS TREES (Cont.)}

E

6 to 12 in. .-.

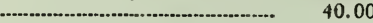

ORIA ovata (Shagbark Hickory)

JUGLANS nigra (Black Walnut)

12 to 18 in.

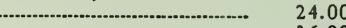

.

JUGLANS cinera (Butternut)

6 to 12 in.

12 to 18 in.

LIQUIDAMBAR (Sweet Gum)

12 to 18 in.

18 to 24 in

LIRIODENDRON (Tulip Poplar)

12 to 18 in.

18 to 24 in.

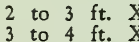

MORUS alba (Russian Mulberrv)

Attractive to birds. Among others, the Grouse, Quail, Lark, Loon, Thrush, Tanager, etc.

6 to 12 in.

12 to $18 \mathrm{in}$.

18 to 24 in

2 to $3 \mathrm{ft}$.

-

(1)

3 to $4 \mathrm{ft}$.

PLATANUS occidentalis (Sycamore)

12 to 18 in

PLATANUS orientalis

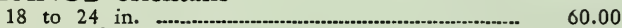

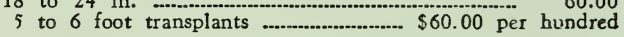

POPULUS (Poplar)

Lombardy and Simon's Poplars

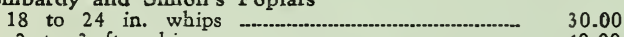

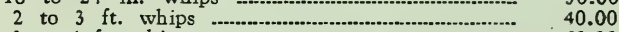

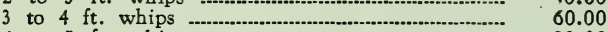

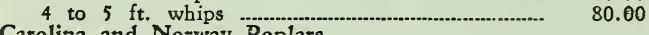

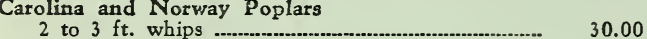

$\begin{array}{lll}2 & \text { to } 3 \mathrm{ft} \text {. whips } \\ 3 & \text { to } 4 \mathrm{ft} \text { whips } & 30.00\end{array}$

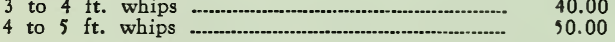

QUERCUS alba (White Oak)

6 to 12 in.

QUERCUS palustris ( $\mathrm{Pin} \mathrm{Oak}$ )

6 to 9 in. S

40.00

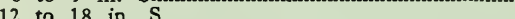

QUERCUS rubra (Red Oak)

6 to 8 in. .... 20.00

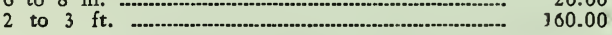

QUERCUS macrocarpa (Burr or Mossycup Oak)

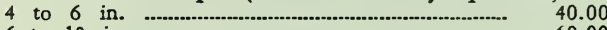

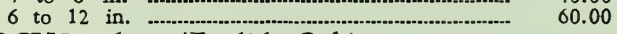

QUERCUS robur (English Oak)

5 to 7 in.

ROBINIA (Black Locust)

12 to 18 in

18 to 24 in.

2 to $3 \mathrm{ft}$.

SALIX babylonica (Weeping Willow)

$\begin{aligned} 12 & \text { to } 18 \text { in. } \\ 2 & \text { to } 3 \mathrm{ft} \text {. }\end{aligned}$

SORBUS aucuparia (European Mt. Ash)

8 to 12 in.

12 to 18 in

18 to 24 in.

3 to 4 ft.

ULMUS americana (Amer. Elm)

12 to 18 in.

18 to 24 in

$\begin{array}{lll}2 & \text { to } 3 & \mathrm{ft} \text {. } \\ 3 & \text { to } & 4 \mathrm{ft} \text {. } \\ 4 & \text { to } & \end{array}$

4 to $5 \mathrm{ft}$.

5 to $6 \mathrm{ft}$.

ULMUS pumila (Chinese Elm)

A new variety, comparatively. Phenomenal growth and hardiness, yet a clean, useful shade tree. Growth of $35 \mathrm{ft}$. and seven inch trunks are reported in trees only eight years from seed.

6 to 9 in

9 to 12 in.

12 to 18 in.

18 to 24 in.

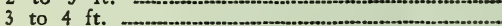

50.00

10.00

14.00

20.00

50.00

80.00

25.00

40.00

80.00

120.00

180.00

10.00

16.00

24.00

50.00

70.00

100.00 


\section{है}

\section{RARE AND SCARCE EVERGREENS, LAWN TREES} AND SHRUBS

To answer the demand for the more unique varieties of plants in small quantities suitable for private plantings, and for those who wish to make a valuable collection, we are offering true grafted varieties of these interesting trees, etc., in lots of 10 or more (5 at the 10 rate).

The grafts listed will be ready for shipment about May first and will be well hardened for safe planting in the open.

These rare varieties will be worth from five to ten times their present value in a few years. Why not plant them in the smaller grades when they can be purchased at reasonable prices?

Prices will be found in the Forestry List commencing on the opposite page and under the following headings:

\section{LAWN TREES}

Acer (Maple)

Japanese Blood leaved Maple

Japanese Cut leaved purple Maple

Japanese Sunrise Maple

Cornus Florida Rubra (Red Flowering Dogwood)

Fagus (Beech)

Purple Beech

River's Purple Beech

Weeping Beech

Fernleaf or cut leaved Beech

\section{EVERGREEN TREES}

Cupresses (Cypress)

Juniperus (Junipers and Cedars)

Picea (Spruce)

Pinus (Pines)

Retinospora (Japanese Cypress)

Thuya (Arborvitae)

Thuyopsis (Blue Nootka Cypress)

Our price-list of Seedlings and Transplants of both Evergreen and Deciduous Stock is pasted in back cover. 



\section{DECIDUOUS SHRUBS}

AMPELOPSIS (Ivy)

A. veitchi (Boston Ivy)

1 yr. 12

A. quinquefolia (Virginia Creeper)

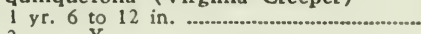

2 yr. X

(100) (1000)

$4.00 \quad 25.00$

$6.00 \quad 50.00$

$4.00 \quad 30.00$

$8.00 \quad 70.00$

ARISTOLOCHIA

Sipho (Dutchmans-pipe)

2 yr. S

6.00

40.00

AZALEA (See Evergreen Shrubs)

BERBERIS (Barberry

Very attractive to birds, including Grouse, Quail, Lark, Loon and Snipe. Provides food all winter.

thunbergi (Japanese)

3 to 6 in. S

6 to $10 \mathrm{in}$.

12 to 15 in. S

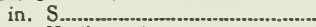

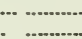

$\quad 12.00$

6.00
12.00
20.00

20.00
100.00

CRATAEGUS (Hawthorn)

coccinea

12 to 18 in. $\mathrm{S}$

oxycantha

12.00

80.00

98.00

CYDONIA (Quince)

japonica (Japanese)

8 to 12 in.

\section{DEUTZIA}

D. Lemoine, Rosea, Pride of Rochester 10 to 18 in

D. GRACILIS

6 to 12 in

\section{FORSYTHIA}

fortunei

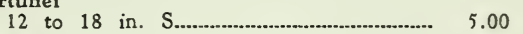

suspensa

12 to 18 in. $S$

\section{HYDRANGEA}

paniculata grandiflora

$$
6 \text { to } 12 \text { in. }
$$

ROSA (Rose)

A planting of roses gives winter food to

Grouse, Prairies Chicken, Bobwhite and Robins.

multiflora

1 yr. No. 1

blanda

12 to 18 in. $\mathrm{S}$

lucida

12 to 18 in. S

6 to 10 in

4.00

$4.00 \quad 24.00$

10.00

75.00

setigera

Climbing Roses: Dorothy Perkins,

White Perkins, Crimson Rambler,

Dr. Van Fleet, Gold Finch, Clb.

Amer. Beauty, Tausendschoen, Sil.

ver Moon, Pauls Scarlet.

$21 / 2$-in. pots

$13.00 \quad 110.00$ wichuriana

1 yr. No. 1

7.50

SYRINGA (Lilac)

persica (Persian Lilac)

12 to 18 in.

12.00

110.00

thmagensis

$12.00 \quad 95.00$

llosa

4 to 6 in. S

vulgaris (Common Purple)

2 yr. S 4 to 8 in.

\section{VIBURNUM}

More than half the native birds relish the berries, including Grouse, Partridge,

Woodcock, Snipe and Phaesant.

V. Lantana

4 to 8 in. $\mathrm{X}$

V. Americana

8 to 12 in.

V. opulis sterilis

5.00

3 to 6 in.

WEIGELA (Diervilla)

rosea

12 to 15 in

10.00

Only a few of the more popular varieties of shrubs are listed here. Write for quotations on any other items you may want. 
